\title{
ILLICIT FINANCIAL FLOWS: THE ROLE OF AL QAEDA AND ITS AFFILIATES IN THE ISLAMIC MAGHREB
}

Theodore Kouts

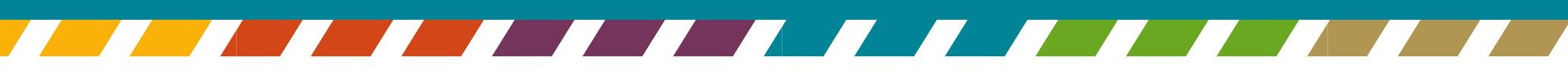

OECD DEVELOPMENT CO-OPERATION WORKING PAPER 63

Authorised for publication by Jorge Moreira da Sllva, Director, Development Co-operation Directorate 



\section{OECD Development Co-operation Working Papers}

OECD Working Papers do not represent the official views of the OECD or of its member countries. The opinions expressed and arguments employed are those of the authors.

Working Papers describe preliminary results or research in progress by the author(s) and are published to stimulate discussion on a broad range of issues on which the OECD works. Comments on the present Working Paper are welcomed and may be sent to catherine.anderson@oecd.org — the Development Co-operation Directorate, OECD, 2 rue André-Pascal, 75775 Paris Cedex 16, France.

You can copy, download or print OECD content for your own use, and you can include excerpts from OECD publications, databases and multimedia products in your own documents, presentations, blogs, websites and teaching materials, provided that suitable acknowledgement of OECD as source and copyright owner is given. All requests for public or commercial use and translation rights should be submitted to rights@oecd.org.

This document and any map included herein are without prejudice to the status of or sovereignty over any territory, to the delimitation of international frontiers and boundaries and to the name of any territory, city or area.

All groups and individuals referred to as terrorists in this report are listed in the UN sanctions regime first established by resolution 1267 on 15 October 1999 and modified by resolutions 1333 (2000), 1390 (2002), 1455 (2003), 1526 (2004), 1617 (2005), 1735 (2006), 1822 (2008), 1904 (2009), 1989 (2011), 2083 (2012) and 2161 (2014) so that sanction measures apply to individuals and entities linked to AI Qaeda as per the UN ISIL (Da'esh) \& Al Qaeda Sanctions List: https://www.un.org/securitycouncil/sanctions/un-sc-consolidated-list .

Please cite this paper as: Kouts, T. (2019), "Illicit financial flows: The role of Al Qaeda and its affiliates in the Islamic Maghreb", OECD Development Co-operation Working Papers, No 63 OECD Publishing, Paris. 
4 |

\section{Abstract}

Illicit financial flows (IFFs) in West Africa have long contributed to the region's instability, partly due to their links to regional terrorist organisations such as AI Qaeda in the Islamic Maghreb (AQIM). AQIM has directly and indirectly participated in and perpetuated illicit financial flows in the region not only through violent means but also through diverse links with the local economy and society. AQIM and its regional affiliates have a profound influence on the political economy of the Sahel and the Maghreb, as well as greater West Africa, and it is important to understand the role played by AQIM in IFFs and the means by which this drives regional instability. This case study examines the political-economic context and the nature and scope of the mechanisms through which AQIM (and its affiliates) operate, with particular emphasis given to their interaction with the local economy and any resulting IFFs. 


\section{Acknowledgements}

The recent OECD Report, Illicit Financial Flows: The Economy of Illicit Trade in West Africa (2018), underlines the importance of better understanding the links between IFFs, development, and globalisation, and works to develop new ways to examine these interconnections. This report contributes to a strategy of the OECD Development Co-operation Directorate to increase data and evidence in the area of illicit financial flows to help address the risks they pose for development. As part of this approach, thirteen illicit economies were analysed, five of which were examined in detail.

This case study on Illicit Financial Flows and AQIM (and its affiliates) is an important contribution to this work, and constitutes one of five case studies produced by the OECD. It was authored by Theodore Kouts, Consultant at the World Bank, with the support of Tuesday Reitano, Deputy Director of the Global Initiative Against Transnational Organised Crime. Launched under the leadership of the OECD Development Assistance Committee (DAC), through its subsidiary body the Anti-Corruption Task Team (ACTT), this work was led by the OECD Secretariat, with substantive editorial support and direction by Catherine Anderson, Team Lead of Governance for Development, and Claire Naval, Policy Analyst, of the OECD Development Co-operation Directorate, Global Partnerships and Policies Division. Our thanks also go to the members of the Reference Group and to Peer Reviewers for, respectively, guiding decisions related to the choice of the case studies and providing valuable comments, inputs and expertise.

The other four IFF case studies focus on illicit narcotics transiting West Africa; illicit trade in counterfeit, pirated and substandard goods in Ghana; human smuggling from West Africa to Europe; and the artisanal and smallscale gold-mining sector in Ghana and Liberia.

Please note that the primary research underlying this report was carried out in 2014-15. Consequently, the problems and the nature of any suggested policy responses may have since changed or evolved. Efforts have been made, where the data is available, to update the analysis and reflect current trends. 
6

\section{Table of contents}

OECD Development Co-operation Working Papers 3

Abstract $\quad 4$

$\begin{array}{ll}\text { Acknowledgements } & 5\end{array}$

1 Introduction $\quad 8$

Malian rebellion $\quad 9$

$\begin{array}{lr}\text { The French military intervention and its impact } & 10\end{array}$

2 Nature and scope of AQIM activities $\quad 11$

Kidnap for ransom $\quad 11$

Smuggling and trafficking 13

$\begin{array}{ll}\text { Contraband and counterfeits } & 16\end{array}$

$\begin{array}{ll}\text { Drug trafficking } & 16\end{array}$

Arms trafficking $\quad 17$

$\begin{array}{ll}\text { Migrant smuggling } & 20\end{array}$

3 Networks and actors behind these financial flows 21

Organisations in constant flux $\quad 22$

4 IFF implications and developmental impact of terrorism-related activities 24

A political economy conducive for IFFs and terrorism $\quad 24$

Sources of IFFs $\quad 25$

Expenditure 26

5 Concluding remarks 28

$\begin{array}{ll}\text { Annex A. Methodology } & 29\end{array}$

$\begin{array}{ll}\text { References } & 30\end{array}$ 
Tables

Table 2.1. AQIM's arsenal in Mali

Figures

Figure 1.1. Map of Mali 99

Figure 2.1. Smuggling and trafficking in the Sahara 14

Boxes

Box 1.1. Origins of AQIM 8

Box 2.1. Boko Haram: Mass kidnappings and funding 12

Box 2.2. Smuggling and the role of Mokhtar Belmokhtar

$\begin{array}{lr}\text { Box 2.3. AQIM affiliates and arms trafficking } & 18\end{array}$

Box 3.1. Prominent movements linked to AQIM and other terrorist networks 21

Box 3.2. Emerging interactions between AQIM and ISIL 


\section{Introduction}

IFFs corrode the state, sow internal conflict and introduce criminality into the economy, creating an environment that is conducive for terrorist and transnational organised criminal groups ${ }^{1}$. Al Qaeda in the Islamic Maghreb (AQIM), an organisation operating in West Africa, has been among the most threatening and longest standing terrorist groups on the Continent. Through the use of pre-existing structures and through the manipulation of regional politics, AQIM has established a financial network spanning Morocco, Algeria, Tunisia, Libya, Mauritania, Mali, Niger and Nigeria (Chivvis and Liepman, 2013). While AQIM's hegemony has faded in recent years, following the splintering of the group and the emergence of new actors, its ability to raise and direct substantial illicit financial flows (IFFs) contributed to its impact and domination as a substantial terrorist threat triggering instability in the West African Region.

Emanating from predecessor Islamist movements and terrorist groups in Algeria, AQIM was a reinvigorated extremist campaign rooted in regional instability. Initially, an Algerian conflict was characterised by sustained civil unrest and an Islamist insurgency against the sitting Government. It later spilled over the country's borders into the surrounding areas. The Malian rebellion in 2012 led AQIM and its affiliates and derivatives to acquire significant holdings in Mali, and demonstrated the strong links between IFFs and sub-state terrorist and rebel groups, as well as criminal organisations. This case study focuses on AQIM, and the way in which terrorist groups can harness the profits of crime to further their objectives. This is a pattern that has continued in subsequent iterations of Sahelian insecurity, thereby also highlighting how the involvement of these groups in IFFs perpetuates regional conflict.

\section{Box 1.1. Origins of AQIM}

Following the emancipation of Algeria from France in 1962 and the subsequent period of civil unrest, militant Islamic social movements gave rise to organisations such as the Groupe Islamique Armé (GIA) and its splinter Groupe Salafiste pour la Prédication et le Combat (GSPC) (Harmon, 2010). AQIM was the formal rebranding of the GSPC. In 2006, Droukdel, leader of the GSPC, swore allegiance to AQ central. He publicly renamed the organisation Al Qaeda in the Islamic Maghreb (AQIM) in early 2007 (UNSC, 2014d). The name change to AQIM was more than symbolic. It also entailed a change in strategy, attacking both Western and local targets. Further, it signalled a change in tactics, with greater reliance on vehicle-borne improvised explosive devices and suicide bombing (Thornberry and Levy, 2011).

AQIM finds its origins in these groups, and has elevated itself among the region's most well-armed groups (BBC, 2013b), drawing technical expertise and battle-hardened terrorists from closely aligned global conflicts, such as between Afghanistan and the Soviet Union (Harmon, 2010). Though AQIM initially maintained a presence in roughly the same area as the GSPC, it gradually shifted its operations to more unstable countries in the Sahel region, notably Mali. 


\section{Malian rebellion}

The political landscape in which AQIM came to prominence was shaped by the Malian uprising of 2012 and French military intervention, which have influenced the nature and impact of ongoing terrorist threats in the region.

Systemic governmental and military corruption, largely involving illicit trafficking in the Sahel, had contributed to a disaffected Malian populace (Tinti, Reitano and Shaw, 2014) such that, in 2011-12, "Islamic extremists, fuelled by Libyan arms, rode the back of a separatist insurgency movement to take all of the major cities in northern Mali," defeating the Malian army (Tinti, Reitano and Shaw, 2014). The newly formed Azawad National Liberation Movement (MNLA) led this separatist insurgency ${ }^{2}$. After the MNLA took control, the Islamist groups, led by AQIM, turned on the MNLA. They captured nearly 821000 square kilometres $(\mathrm{km} 2)$ of territory in Mali alone (Blair, 2012). This area included the cities of Timbuktu, Gao, Tessalit and Kidal, and a population of approximately 1.3 million people (Figure 1.1). In addition, AQIM was able to forcibly acquire infrastructure, arms and vehicles, adding to the group's regional stature (Blair, 2012). At the time of the Malian rebellion, US Africa Command Commander, General Carter F. Ham, remarked that AQIM is "Al Qaeda's best-funded, wealthiest affiliate" (US AFRICOM Public Affairs, 2012).

\section{Figure 1.1. Map of Mali}

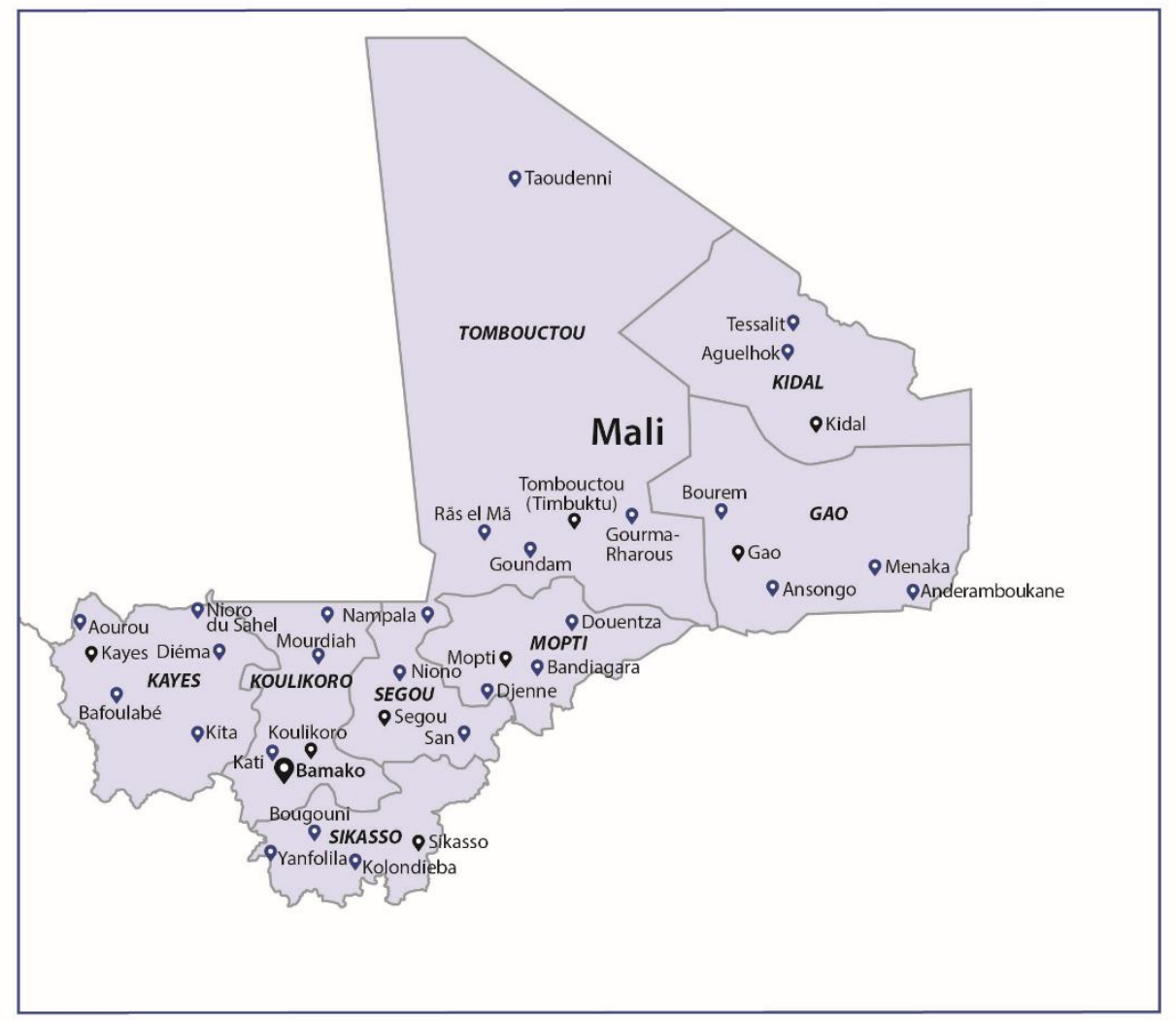

Source: UN (2013) "MINUSMA United Nations Multidimensional Integrated Stabilization Mission in Mali: MINUSMA Resources" www.un.org/en/peacekeeping/missions/minusma/resources.shtml, 


\section{The French military intervention and its impact}

Watching the shifting tide within Mali and after the attack on the strategic city of Konna, France took military action to bring stability to the country (Ahmed and Corbet, 2013). Operation Serval began in January 2013, and later received troops from the African Union and the Economic Community of West African States (ECOWAS). It also received support from the United Nations Security Council (Ahmed and Corbet, 2013; Camara, 2015).

Operation Serval had several goals. It sought to neutralise the terrorist threat, protect French citizens and free French hostages held by AQIM, and prevent Mali from coming under Islamist control, which would upset regional stability (Shurkin, 2014). French military intervention forced the Islamist movements, including AQIM, out of the major Malian cities. Withdrawing to northern Mali, a less populated region, enabled these groups to continue a counteroffensive against external forces and maintain local terrorist activities (Rasmussen, 2015). A threat report produced by the United States suggested that French military advancements had weakened the strength and operational purview of AQIM and its affiliates, which gave the Malian government the opportunity to regain control of the country (US Department of State Bureau of Counterterrorism, 2014). Although the continued AQIM presence in the Maghreb and persistent terrorist attacks suggest the international response did not significantly reduce the strength of AQIM. ${ }^{3}$

Operation Serval ran its course, replaced by Operation Barkhan in July 2014. The new operation assigned 1000 French troops to Mali and another 2000 among Mauritania, Burkina Faso, Niger and Chad (Vanguard, 2014; Weiss, 2014a). Alongside Operation Barkhan, the UN Multidimensional Integrated Stabilization Mission in Mali (MINUSMA) supported transitional authorities in Mali. In 2014, it allocated a working force of 11510 uniformed personnel and 1190 civilians to regional efforts (UN, 2015).

In spite of these prolonged international efforts, continued terrorist attacks were documented in 2014. Concurrently, Ansar al-Dine (AAD) and Mouvement pour l'Unification et le Jihad en Afrique de l'Ouest (The Movement for Oneness and Jihad in West Africa, or MUJAO) were reportedly returning to areas such as Telakak, Bakasso, Djebock (close to Gao) and north of the Adrar Tigharghar Hills. In addition, they maintained a presence in the Dorayat valley. This return of Islamist forces was accompanied by attacks on French, Chadian and Malian forces (Follorou, 2014). Moreover, following the French intervention, AQIM and its affiliates carried out 34 significant attacks in Mali and 5 in Niger in 2014, and another 45 in Mali in 2015 (Weiss, 2015c).

Superficially, the French military intervention in 2013 did not affect AQIM - their financial networks do not appear to have been significantly affected - although it pushed both AQIM and its affiliates into ungoverned and remote territories. Interlocutors in major Malian towns confirmed that the introduction of MINUSMA had a nominal impact on illicit trafficking. According to these interlocutors, the principal main change was a tactical switch by traffickers to smaller convoys due to increased aerial surveillance (Tinti, Reitano and Shaw, 2014). Attacks continued in northern Mali and in Algeria. In 2014, the US Department of State Bureau of Counterterrorism, reported that AQIM and its affiliates "are leveraging the lack of governance and abundant terrorist networks in Libya to regroup". French military intervention may also have been counterproductive, perpetuating a pattern of sustained aggression in the region and likely contributing to a reciprocal call-to-arms by Islamist groups to attack French interests domestically and abroad.

With its consistent targeting of AQIM and its operatives, the French led military intervention can be said to have contributed to the fragmentation of the nature of the terrorist threat in the Sahel. Prior to 2012, AQIM was the only terrorist group active in Mali, but, by 2018, more than 10 groups can be identified with established identities and hierarchies. These groups have expanded in the Sahel, to encompass Mali, Burkina Faso and Niger. The number of reported incidents of terrorist violence have more than doubled every year since 2016 (from 90 in 2016, to 194 in 2017, and 465 in 2018), with the number of reported fatalities following a similar trajectory. Violent episodes in 2018 exceeded all activity observed from 2009-2015, the period covered by this case study (START, 2019). 


\section{Nature and scope of AQIM activities}

This portion of the working paper will discuss the financial structure of AQIM in the context of the Malian political economy. It breaks down the revenue sources that AQIM had access to during their period of growth and consolidation (between 2003-2012) as they pertain to IFFs, and seeks to dispel misconceptions around AQIM's fund-generating activities in the region. It shows that, in the Sahel, AQIM predominantly relied on kidnap for ransom, smuggling and trafficking for funding.

\section{Kidnap for ransom}

Kidnap for ransom (KFR) played a central role in AQIM's business model, and constituted the financial foundation of its campaign, while also reinforcing its ideological impact. The vast desert expanses of the Sahel combined with minimal governance create an environment conducive to KFR operations (CSS ETH Zurich, 2013). KFR is a protracted process that involves abduction, captivity, proof of life, negotiation and, in successful cases, ransom delivery and release. The proof of life and negotiation aspects often involves the manipulation of public sentiments through media outlets, making it easier to track hostage cycles (Weiss, 2014b). Thus, the extent to which AQIM and its affiliates were involved in KFR was more easily identifiable than other illicit revenue-generating activities in which these groups took part, and contributed to reinforcing the messages of threat to western interests that form an integral part of the group's ideological foundation and reputation.

The 2003 kidnapping of 32 European hostages in Algeria appears to have been the first time that AQIM's predecessor, GSPC, engaged in KFR. Millions were paid for the safe release of the captives (Der Spiegel, 2007). Following this heavily publicised event, KFR increasingly became a source of funding for criminals and AQIM because of its low investment, low risk, quick returns and plentiful targets (Global Initiative, 2013). The targets of KFR abductions are predominantly Westerners visiting the region or those on work assignments. These include aid workers, diplomats or employees of international organisations or multinational corporations (Laub and Masters, 2015). AQIM wants to reduce the risks associated with KFR operations, as well as the needed personnel. To that end, it has reportedly offered USD 100000 for Western captives from countries other than the United States due to the latter's strict ransom policies (Letouze and Cramer, 2013).

Between 2003 and 2011, AQIM and its affiliates "kidnapped a total of 54 Westerners - German, French, Canadian, Swiss, Spaniard, British, Austrian and Italian - and 3 African nationals from Burkina Faso, Togo and Madagascar" (Ould, 2011). On its own, AQIM is alleged to have "carried out over 20 kidnapping operations and abducted 60 foreigners" (CSS ETH Zurich, 2013). Not all of these abductions ended in a successful ransom payment. The instability, sustained military activity and elevated risk for visiting nationals of western countries during the Malian rebellion limited the opportunity for KFR operations by AQIM and its affiliates. In 2011, AQIM abducted five individuals in two separate events and held them throughout the coup d'état. All but one kidnapping in Mali and Algeria since these 2011 events have resulted in failed abduction operations or the death of the hostages in captivity (Sahara Overland, 2015).

The trend of increased kidnapping attempts, however, emphasises the elevated importance of this revenue source for AQIM and its affiliates (Flood, 2011), as illustrated in Box 2.1 and the reference to Boko Haram's use of kidnapping. AQIM and its affiliates' use of KFR as a source of revenue and will continue as long as these groups are able to acquire appropriate hostages, and for as long as their governments or private insurance 
companies are prepared to pay the ransoms. Its boost in the eyes of regional terrorist groups has been directly linked to the ransom payments they have received over the years. However, KFR is heavily influenced by security in the region, international western staff continuing to be deployed there, as well as shifts in the international climate surrounding the issue of ransom payments. As the Sahel has become increasingly insecure (largely due to the expanding terrorist operations in the region), the number of available KFR targets has reduced. The availability of KFR to serve as a significant source of financing is also shaped by the ability of the hostage-taking groups to influence public sentiments and effectively pressure nations into making concessions.

\section{Box 2.1. Boko Haram: Mass kidnappings and funding}

Boko Haram is another Islamic extremist organisation active in West Africa that is renowned for its involvement in kidnapping. As such, it therefore serves an interesting counterfactual on how KFR can be used strategically to generate IFFs and contribute to ideological objectives of terrorist groups.

Boko Haram, a group that originates from Nigeria, became the focus of international media in 2014 when the group abducted 219 girls from a school in Chibok of Borno State (Newton, 2015). Although this particular case was widely publicised, Boko Haram's practice of kidnapping has been consistently extensive, and is a critical part of their revenue and terror strategy.

In mid-October 2015, Nigeria's House of Representatives issued a statement that around 45000 Nigerians have been kidnapped since 2012. Amnesty International estimates Boko Haram has abducted at least 2000 girls and women since 2014 (Smith, 2015; Voice of Africa, 2015a). In 2018, more than 100 schoolgirls were kidnapped from the northern Nigerian town of Dapchi. They were subsequently released, reportedly without any ransom being paid (Maclean, 2018). The majority of the group's targets are Nigerian citizens, particularly young, female hostages who are targeted to retain the loyalty of the male conscripts, and are forced into marriages and subjected to rape (Matfess, 2017). They are also used for labour, military operations and the transportation of stolen goods, war materials and funds (Sherwood, 2014). The targeting of young schoolgirls aligns with one of the group's ostensible ideological objectives: i.e. to prevent youth from receiving a western education (Matfess, 2017).

KFR is less of a lucrative fundraising strategy for Boko Haram, as it was for AQIM. The organisation has received some substantial ransom payments, including USD 3.15 million paid for the release of French hostages in 2013, but these are far less frequent. Instead, Boko Haram has adopted opportunistic fundraising modalities that are often times criminal, and tend to shift according to international pressure and action. For example, prior to military offensive of February 2015 Boko Haram enjoyed a structured and consistent financial network (BBC, 2015c). Intergovernmental actions then scattered the group within the northeast and its bordering areas, and this, in turn, has impacted on its financial infrastructure (NIG-Gov-LE-201015).

Initially, Boko Haram received funding from the habitual sale of goods, the collection of alms by child beggars and the physically challenged, as well as internal donations from members. It also received external donations from sympathisers, protection schemes and individuals conducting legitimate businesses (NFIU, 2013). The group was consistently involved with arms smuggling and arms dealing, which provided both funds and weapons, as well as in the sale of second-hand vehicles. It also received financial contributions from political leaders and associated terrorist organisations such as AQIM (FATF and GIABA, 2013).

Boko Haram used to rely on extortion (targeting communities, companies and state governments), kidnap for ransom, and extensively targeted bank robberies as its main sources of revenue (NIG-Gov- 
Sec-121015), with the result that banks withdrew from certain regions, creating problems of financial exclusion (NIG-Gov-LE-201015).

2015 has proven to be a peak year for Boko Haram. Nigerian President Buhari's campaign pledge to remove the terrorist threat by the end of 2015 led to a concerted military campaign backed by the international community that has significantly affected Boko Haram's territorial control and, consequently, its ability to generate and collect funds (Ugwuanyi, 2015). From more than 5,000 in 2015, the number of deaths attributed to Boko Haram has reduced substantially, to less than 1000 a year for the subsequent three years (ACLED, 2019). The Nigeria Security Tracker, which monitors media reports of KFR, also found that the majority of kidnappings fell in 2014-15, when Boko Haram was at its strongest militarily, but that the geographic scope has widened, and increasingly targets soft targets like schools and villages (Giles, 2019).

Boko Haram was no longer able to make use of the more sophisticated funding mechanisms previously used, and had to focus instead on making "quick money", i.e. robbing markets and market people; stealing supplies, food and money from local populations; and taxing people wherever it is dominant (NIG-Gov-Sec-121015). The group continues to receive donations but uses kidnap for ransom less due to the increased difficulties resulting from technological advancements (NIG-Gov-Sec-121015). Boko Haram also struggles to create a consistent source of financing, such as a smuggling network, because these are cumbersome (NIG-Gov-Sec-121015) and the group's area of territorial control does not coincide with an established illicit trafficking route.

Cattle rustling has recently emerged as a major issue in northern Nigeria, and although Boko Haram is not believed to have direct ties to rustlers, its insurgency is considered to have led to the insecurity that now allows rustling to happen (Ibrahim, 2015). Moreover, as the group's ability to raise funds through traditional means shrinks, cattle rustling may provide an alternate source of illicit revenue.

In the counter-terrorism climate generated by military campaign in Nigeria and its border nations, Boko Haram has exhibited a desire to survive at all costs. Like AQIM, however, the pressure applied by the campaign has resulted in a displacement of the group from its traditional geographic strongholds, as well as a fragmenting of the previously relatively unified and hegemonic group. With mounting military pressure and counter-terrorism efforts, Boko Haram's resource mobilisation strategy availed of every local resource to endure (BBC, 2015b). Signs of Boko Haram's desperation include increased attacks and the group's use of any available means of funding, particularly those targeting local populations.

\section{Smuggling and trafficking}

Although kidnap for ransom (KFR) was, for some years, the main source of revenues in AQIM's financial network, the one that most changed the group's trajectory and consolidated its profile as a serious international security threat, smuggling across the Sahara is also a mainstay of the organisation. It provides AQIM, and other militia extremist groups, with funds, as well as a means to acquire weapons and other essential resources. Changes in smuggling patterns and flows have directly impacted the fortunes of different groups, in some cases allowing them to persist despite increased regional and international pressure. 
Figure 2.1. Smuggling and trafficking in the Sahara

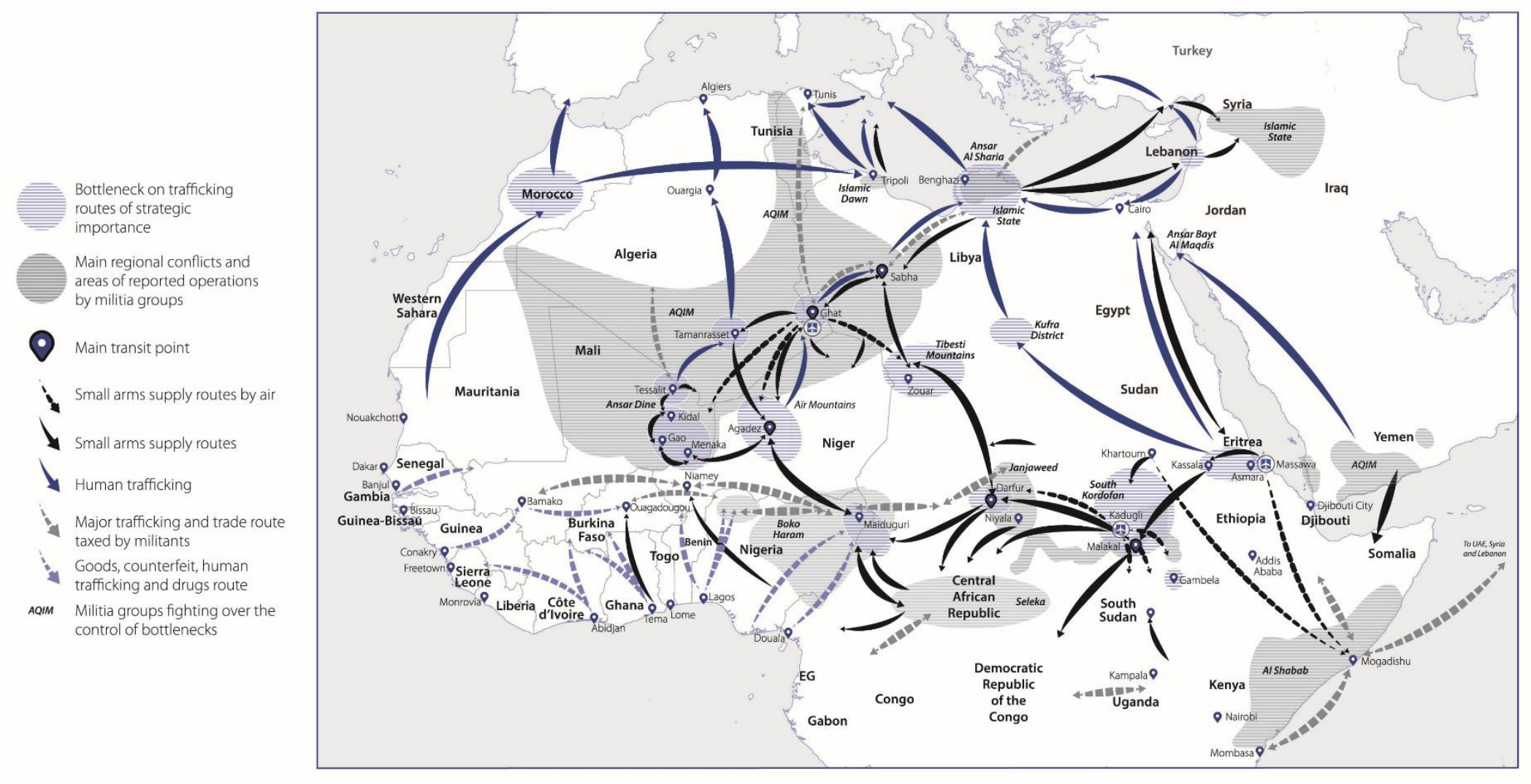

Source: The Global Initiative and RHIPTO (2015) "Libya: A growing hub for criminal economies and terrorist financing in the Trans-Sahara", www.globalinitiative.net/download/global initiative/Libya\%20Criminal\%20Economies\%20in\%20the\%20trans-Sahara\%20-\%20May\%202015.pdf.

ILLICIT FINANCIAL FLOWS: THE ROLE OF AL QAEDA AND ITS AFFILIATES IN THE ISLAMIC MAGHREB @ OECD 2019 
AQIM's collective experience and knowledge of smuggling is a product of the region in which it operates. West Africa, specifically the Sahel region, is notorious for its extensive and intricate smuggling networks (Figure 2.1). In this region, smuggling and trafficking networks are deeply embedded in vast undergoverned territories, porous borders, state corruption, poverty and lack of economic opportunities. According to a focus group study, local populations do not view trafficking and smuggling as a criminal activity, regardless of the commodity. Rather, they are viewed as revenue sources and lifelines for communities. The same study suggested that a single trafficking opportunity could generate up to USD 6000 for a driver transporting cigarettes and USD 14000 for drugs (Reitano and Shaw, 2014).

\section{Box 2.2. Smuggling and the role of Mokhtar Belmokhtar}

Mokhtar Belmokhtar, is a prominent name in the smuggling networks of West Africa, and a lifelong fighter with activities dating back to the Afghanistan-Soviet conflict in the 1980s. On his return to Algeria, Belmokhtar promptly joined the GIA, staying with the organisation as it transitioned into the GSPC and later AQIM (Reitano and Shaw, 2014). Famed for his control of smuggling routes in the Sahel, Belmokhtar was a preeminent leader of AQIM until 2012, when he defected with his smuggling network to form al-Mouakaoune (McElroy, 2013; UNSC, 2014c), and then later Al Mourabitoun, a merger between al-Mouakaoune and MUJAO, the leading brand of the secessionist movement in the Northern Mali 2011 conflict.

Belmokhtar prospered due to his ability to create and control cigarette smuggling routes in the Sahara. In an illustration of the magnitude of tobacco smuggling in the region, and Belmokhtar's impact, "the Maghreb states of Algeria, Egypt, Libya, Morocco and Tunisia smoke 44\% of Africa's cigarettes, and the illicit trade in tobacco is said to be worth USD 1 billion per year, with Mali being a major distribution hub thanks to the networks established by Mokhtar Belmokhtar" (Global Initiative and RHIPTO, 2015). It is said that, during his tenure with the GSPC/AQIM, "Belmokhtar, together with Saifi Ammari, respectively, masterminded smuggling and KFR operations, of the organisation's KFR operations (UNSC, 2013, 2010), in the latter case establishing a network of facilities, fuel and food depots, as well as secure transport links.

Belmokhtar has led his own Islamist organisations since 2012, initially remaining loyal to the central senior leadership of $A Q$ and using his own resources to fund several attacks in its name (Joscelyn, 2015b). Since 2017, however, he has increasingly separated from the AQ brand, allying under the broad umbrella of the Jama'at Nusrat al Islam wal Muslimeen (JNIM) coalition that was founded in March 2017 (ACSS 2019), although reportedly continuing to supply a wide range of groups, including AQIM, with essential contraband and counterfeits. It is thought, for example, that AQIM still uses the infrastructure and strategy developed by him, but that their use has been reduced due to the connections and trade routes that were naturally kept by Belmokhtar when he left AQIM.

It is not known whether Belmokhtar is still alive. He was reportedly killed in a French airstrike in southern Libya in November 2016, and his profile has been low in following years. However, this is not the first time he is reported dead - he was said to have been killed both in 2013 and 20135 but subsequently resurfaced (Usborne, 2016). Leadership of Al Mourabitoun, Belmokhtar's AQIM splinter group, passed to Hasan Al-Ansari, one of the co-founders, but his own confirmed death in March 2018 has left the group in a fragile state, likely to be absorbed back into the broader JNIM coalition (Weiss, 2018). That said, in 2018, reports of Belmokhtar being alive and active began to circulate again (Ahmed, 2018), keeping the mythology surrounding the Sahel's single most prominent and notorious terrorist alive.

AQIM and its affiliates are actively engaged in trafficking and smuggling in Mali and its surrounding countries at both organisational and individual levels, although an important distinction exists between 
group members independently engaging in trafficking as a means of survival and the organisation undertaking such activities as a means of control and profit. The following section of this case study will explore trafficking and smuggling as operational activities undertaken by AQIM.

\section{Contraband and counterfeits}

Smuggling is directly linked to the political and physical control of a territory, whereby groups are able both to engage directly in moving contraband goods, and to tax other trafficking flows moving through areas under their control. Over the years, AQIM's political standing and territorial control has fluctuated and this has affected its ability to smuggle and tax goods. Individual members of AQIM have also played a central role in smuggling activities, which in turn has altered the organisation's strategy, structure and operations.

The rate of smuggling and trafficking of both illicit and licit goods, and the types of goods smuggled, especially by AQIM, its affiliates, rebel groups and nomadic tribes, are linked to their potential for profit. In earlier years, mainly legal goods were smuggled. This later evolved, through a gradual shift from trafficking of licit to illicit goods, switching first to cigarettes and more recently to narcotics (Reitano and Shaw, 2014). Drug trafficking produces the highest income, using the same routes and trafficking techniques established for illicit tobacco (Reitano and Shaw, 2014). Generally, the smuggling of contraband and counterfeit goods, other than cigarettes, is used to "boost revenues or cover the costs of a return trip". It "do[es] not systematically contribute to the financing of specific groups or conflict actors" (Global Initiative and RHIPTO, 2015).

\section{Drug trafficking}

Located en route from South America (a major source) to Europe (a major consumer centre), West Africa was for a while, a popular transit area for illicit narcotic drugs. Cocaine trafficking from South America to Europe through West Africa increased over the previous decade, reaching its peak in 2007 and making the region a prominent "trans-shipment hub" (UNODC, 2013b). Cocaine shipments across the Sahel in 2012 nevertheless yielded USD 1.2 billion in profits, of which USD 500 million was laundered locally (Campbell, Bunche and Pham, 2014). The case study on illicit narcotics (Working Paper n.2 Illicit narcotics transiting West Africa) estimates that up until 2015 some 35-40 tonnes of cocaine were crossing the region annually, which suggested that West Africa and its inhabitants retained an integral and quite complex role in transnational drug trafficking.

Seeking to avoid economic or judicial risks, drug traffickers gravitate towards under-governed regions where states are unable to enforce rule of law.

West Africa's "poor internal transport and communications systems, porous land and maritime borders, lack of marine, air and land surveillance and interdiction technical capacities, weak law enforcement and judicial systems, limited state regulatory controls and administrative capacities, and high rates of poverty and unemployment" have created an ideal environment for smuggling in the region, especially for drug trafficking. (Anon, 2013)

This combination of factors has allowed members of the criminal underworld and terrorist organisations to attempt to make profits through drug trafficking, and there has been growing concern about AQIM's involvement. Moroccan and French officials have gone on record declaring a connection between regional terrorist groups and drug trafficking in Mali and Mauritania (Rotella, 2009; Powelton, 2012), although the degree to which AQIM and its affiliates are involved in the industry remains unclear. Many claim a substantial overlap, while others argue any links are tenuous. 
Literature pointing to a direct link between AQIM and drug trafficking cites a few highly publicised cases. One involves undercover DEA agents, another participation in a drug summit. ${ }^{4}$

Other events have also contributed to the idea that terrorism and drug trafficking are somehow connected. In 2009, for example, a Boeing 727 carrying up to 11 tonnes of cocaine from Venezuela crashed near Tarkint, Mali. The area of the crash has a large AQIM presence (Freeman, 2013). The UK Serious Organised Crime Agency reported a similar occurrence in 2010 when a plane from Venezuela landed in Mali, where its cargo was offloaded and transported via land to Timbuktu before authorities lost track of the vehicles (Hirsch, 2013b).

Overall, however, literature and media reports documenting narco-terrorism links are typically based on "anecdotal or disputed evidence" (Gberie, 2015). For example, the US v. Oumar Issa, Harouna Toure and Idriss Abdelrahman case failed to establish a link between AQIM and FARC and the narco-terrorism charges against the defendants were eventually dropped (Lacher, 2013). Political viewpoints also influence statements issued by governments, which occasionally leads to the inflation of drug-terror relationships (Lacher, 2013).

Aside from drug trafficking itself, AQIM is also rumoured to profit indirectly through taxation and protection rackets. Prior to the French military initiative in 2013, AQIM allegedly levied taxes on local drug traffickers (Luna, 2014). An AQIM imposed "service fee" was reportedly associated with the movement of drugs, cigarettes, arms, medicine and people through its territories (Brown, 2013). This was corroborated by the US Department of State and other Western law enforcement officials. They reported that drug traffickers arrested by Moroccan authorities had stated that USD 50000 was required to transport a convoy of hashish through AQIM territories (Lewis and Diarra, 2012). Moreover, regional inhabitants have observed terrorists and drug traffickers to be closely aligned in a system that involves local businessmen and politicians (Lewis and Diarra, 2012). The ability of AQIM to exact funds from drug traffickers is linked to the control it exerts over territory. AQIM needs only to possess more power and influence than its drug trafficking counterparts to have the ability to coerce them to pay protection fees.

The French and American counter-terrorism operations, the UN and EU peacekeeping forces in the Sahel, and the increased international focus on trans-Saharan trafficking routes facilitating irregular migration, have served to dramatically reduce the scale of those flows, which for some years (2015-17) appeared to have stopped altogether. The fragmentation of the Islamic extremist and militia groups across the Sahara has meant that territorial control patterns and relationships can no longer be as easily developed and maintained. Groups in the Sahel have competed with each other, reportedly attacking convoys and seizing their contents. High value illicit narcotics, such as cocaine, unpredictable territorial control, and the risk of banditry have made land transit routes across the Sahara relatively unattractive. Largescale seizure patterns along the West African littoral and in Algeria suggest that drug flows are now predominantly seaborne, and that little opportunity remains for AQIM, or any of its derivatives, to traffic or tax drug flows.

\section{Arms trafficking}

Arms trafficking is an essential trade for AQIM and its affiliates, one that directly affects their regional influence and enables their pursuit of organisational goals. The evidence suggests that "control of and access to arms in the Sahel and the Sahara [is] a critical factor in the ability to control trade routes, establish territorial control and challenge the state's monopoly over the use of force" (Reitano and Shaw, 2015). In particular, the Tuareg uprisings in northern Mali signal that "access to weapon stocks was closely correlated with the degree of success of each rebellion" (Reitano and Shaw, 2015).

Understanding AQIM's relationship to arms trafficking requires an understanding of the Sahel environment. The overthrow of the Gadhafi regime in 2011 in Libya and the resulting instability of the country allowed 
easy access to Gadhafi's arsenal of light and heavy arms, and regional arms traffickers and rebel groups in neighbouring countries have profited.

The Libyan crisis in 2011 contributed to the rebellion in Mali through the supply of conventional weaponry and former soldiers, in an already unstable and tense country due to the region's decade-old arms trade (Kavanagh and Ellis, 2014), where firearms were already in wide circulation across the region as a result of prior conflicts. Many dissidents of the Malian army also absconded with their weapons to join rebel groups before and during the rebellion (Shurkin, 2014). Nevertheless, the exact nature and scope of AQIM's ability to acquire arms and its involvement in arms trafficking are difficult to determine although the organisation clearly seeks to amass weaponry when it is opportune to do so. The types and numbers of weapons trafficked from Libya were estimated at 17000 man-portable air defence systems (MANPADS) (of which only $2.5 \%$ have been seized by authorities in the region) and between $10000-20000$ firearms (UNODC, 2013a).Internal documentation recovered from AQIM detailed how European ransom payments acquired by the organisation were immediately used to buy weapons to attack Western targets (Callimachi, 2013b).

\section{Box 2.3. AQIM affiliates and arms trafficking}

Mouvement pour l'Unification et le Jihad en Afrique de l'Ouest (The Movement for Oneness and Jihad in West Africa), or MUJAO is thought to be "heavily armed". Its arsenal allegedly includes "heavy machine guns (14.5 and $23 \mathrm{~mm}$ ), anti-tank grenade launchers (RPG-7), mortars (60 and $82 \mathrm{~mm}$ ), conventional (TNT) and home-made explosives, night-vision binoculars and means of communication (mobile and satellite telephones, and VHF radios)" (UNSC, 2014b).

Similarly, lyad Ag Ghaly, a native Tuareg and leader of the AAD, reportedly purchased large numbers of weapons for minimal cost from ex-government stockpiles (Mben and Puhl, 2013).

With the estimated revenue from KFR alone, AQIM could have spent tens of millions of dollars on the procurement of weapons. AQIM leaders, such as Belmokhtar and Abu Zeid, are rumoured to have used substantial funds from kidnapping to amass stockpiles in southern Libya. This includes, above all, small arms and light weapons (SALWs) originating in Eastern Europe (Chivvis and Liepman, 2013). The Libyan crisis and AQIM's surplus of funds may have also enabled AQIM to buy or steal heavy weaponry such as anti-aircraft and anti-tank missiles from Libya in 2011 (Ould, 2011). North African security officials and state leaders have recorded major caravans carry SALWs, as well as larger conventional weaponry, MANPADs and munitions from Libya through Chad and Niger to northern Mali, implying that AQIM and its affiliates may have been hoarding arms in the Sahel (Lebovich, 2011).

The 2012 Malian rebellion provided AQIM and its affiliates many opportunities for looting weaponry from government forces. When the Malian military crumbled in the rebel-led Islamist-backed attack, AQIM and its affiliates absorbed any abandoned arms and military vehicles left by retreating forces. This cache of weaponry may not have directly contributed to arms trafficking, but it has contributed to the proliferation of arms in the region. Given the many Islamist military victories in 2012, a substantial number of weapons were acquired in this way. One report stated that "stores" of artillery, small arms, ammunition and rocket launchers were taken. The same report said the United States had issued 87 land cruisers and navigation equipment to six Malian counterterrorism units. The army deserted five of them when terrorists stormed their position. All of this is in addition to the infrastructure that also fell under the control of terrorist forces, including civilian airports and the military airbase in Tessalit (Blair, 2012).

Similar to research on drug trafficking and AQIM, much information on AQIM and arms trafficking is inconsistent, often anecdotal. It does not provide solid evidence regarding the movement or receipt of weapons by AQIM and its affiliates. One method for better estimating AQIM's involvement is to examine 
the number of weapons that have been recovered or visually documented in its arsenal (Table 2.1). It is thought that verifiable seizure operations and weaponry that is subsequently confiscated could provide an accurate account of AQIM holdings, and those of its affiliates. Such seizures presumably include AQIM weapon purchases, as well as those acquired through active participation in arms trafficking and looting of military reserves.

\section{Table 2.1. AQIM's arsenal in Mali}

\begin{tabular}{l|l|l|l|l}
\hline Many & Some & Reported * & Many & Some \\
\hline AK-47 assault rifles & Semtex & $\begin{array}{l}\text { SA-7 surface-to-air } \\
\text { missiles }\end{array}$ & AK-47 assault rifles & Semtex \\
\hline $7.62 \mathrm{~mm}$ ammunition & $\begin{array}{l}\text { HE detonators/ trigger } \\
\text { devices }\end{array}$ & .50 Calibre DSHK (AA) & $7.62 \mathrm{~mm}$ ammunition & $\begin{array}{l}\text { HE detonators/ trigger } \\
\text { devices }\end{array}$ \\
\hline $\begin{array}{l}\text { Various nondescript } \\
\text { handguns }\end{array}$ & PK 7.62mm GPMG & F2000 assault rifles & $\begin{array}{l}\text { Various nondescript } \\
\text { handguns }\end{array}$ & PK 7.62mm GPMG \\
\hline $\begin{array}{l}\text { Storage cases / strong } \\
\text { boxes }\end{array}$ & RPG-7 & AK-103 assault rifles & $\begin{array}{l}\text { Storage cases / strong } \\
\text { boxes }\end{array}$ & RPG-7 \\
\hline Many & Some & Reported * & Many & Some \\
\hline
\end{tabular}

Source: Reproduced from Chivvus and Liepman (2013), "North Africa's Menace: AQIM's Evolution and the US Policy Response", Research Report Series, Rand Corporation, www.rand.org/pubs/research_reports/RR415.html.

Notes: "Many" corresponds to verified open sources, AQIM pictured with actual weapons, unknown quantity. "Some" refers to reported open source, AQIM pictured with some weapons, evidence of weapons used in the Sahel region, unknown quantity. "Reported" are suspected open sources (not verified), AQIM/Tuareg rebels pictured with few weapons, AQIM statement of acquisition, no evidence of weapon use, unknown quality.

Specific instances of weapon seizures are telling in terms of AQIM's arms holdings. In 2011, for example, the Nigerien army seized an AQIM vehicle carrying $640 \mathrm{~kg}$ of explosives and 435 detonators (Agence France Presse, 2011). The same year, Moroccan authorities broke up a 27-member AQ-linked cell, uncovering weapon caches of 30 Kalashnikov rifles and 2 anti-tank rocket-propelled grenade systems (Alaoui, 2011). While many weapon seizures occur by chance, others result from military initiatives to seek out and recover war materiel from Islamist factions in Mali (Reuters, 2013). In one of the largest discoveries, a weapon cache was found in northern Mali, believed to belong to extremists. It contained "tonnes of heavy weapons, suicide belts and equipment for improvised explosive devices" (Meilhan and Botelho, 2013).

One can also confirm the scale of weapons possession by examining equipment used by AQIM and its affiliates in attack. Open source photography and videos in the media have provided a wealth of information that has allowed verification of weaponry held by Malian militants, including in some cases on its origins (Conflict Armament Research and Small Arms Survey, 2013). In the 2013 Algerian gas plant attack by Belmokhtar's organisation, Semtex explosives were rigged to hostages. Numerous four-wheel drive vehicles were also used (Chrisafis et al., 2013). From images following the French military intervention in Mali and the subsequent militant retreat from key cities, Malian rebels were found to be in possession of heavy weaponry. This included BM-21 $122 \mathrm{~mm}$ multiple rocket launch systems and $122 \mathrm{~mm}$ towed howitzers, as well as armoured personnel carriers (Conflict Armament Research and Small Arms Survey, 2013). Some of this light and heavy weaponry was originally sourced in Libya. In most cases, however, no definitive conclusions can be drawn as there is insufficient information about the post-Cold War Libyan arsenal, and poor resolution in the film and photo material (Conflict Armament Research and Small Arms Survey, 2013). There is a higher degree of certainty, however, that rebels and extremists seized military weaponry from the Malian military posts in their assault on Gao, Kidal and Timbuktu (Conflict Armament Research and Small Arms Survey, 2013). 
According to some, the potential weaponry in the coffers of AQ-linked Sahel-based groups more closely resembles that of a small army than a militia (Wood, 2013). In an interview with an AAD member responsible for illegal arms imports from Libya (Mben, 2015), and referring to the AAD arsenal hidden in caves northeast of Kidal, the respondent boasted "the Europeans have no idea how much material we have hoarded in the last few years" (Mben, 2015).

Although it is unclear the extent to which AQIM has financially profited from the arms trade, through purchase, looting and presumably bartering, the evidence suggests that AQIM has amassed a formidable arsenal. Moreover, it also plays a major role in the distribution of weapons in West Africa, contributing to the region's instability.

\section{Migrant smuggling}

In addition to involvement of AQIM and its affiliates in the trafficking of contraband, counterfeits, drugs and arms, these groups are commonly also linked to the transport of humans across the Sahara for trafficking or smuggling. Anecdotal reports suggest that the AQIM's control of Sahel trading routes has allowed it to make money, and it has done this through the taxation of human smuggling convoys, as well as through the co-ordination of its own smuggling and labour exploitation operations (Harmon, 2014). Human trafficking is focused on the criminal exploitation of individuals. However, migrant smuggling is often a voluntary transaction between migrants and smugglers (US Department of State, 2006).

The involvement of the Tuareg community in migrant smuggling in the Sahel could ostensibly be linked to AQIM's engagement in this practice. "Members of the Tuareg tribe are thought to be active on the routes through North Niger and Algeria and to Ghat and Debded in Libya." This is facilitated by their nomadic lifestyle, regional navigation and survival skills, and participation in the trans-Saharan caravan trade (Malakooti, Benattia and Davin, 2013). The relationship between the Tuareg population and AQIM and its affiliates - both the large Tuareg membership in regional terrorist movements, as well as the financial alliances between these groups and local populations - support the conclusion that terrorists may consider migrant smuggling profitable. Moreover, it is not uncommon for many businessmen in Kidal and Gao to have connections to traffickers, smugglers, corrupt officials, rebels and terrorist groups. It is alleged they "import goods from Algeria and return the trucks full of migrants" (UNODC, 2013a). The smuggling of persons is a "local control industry," with no distinguishable head and the money is absorbed into the local economy (UK-Gov-Sec-230615).

The ongoing instability in Libya and the country's easy access to Europe have generated highly lucrative trans-Sahel migrant smuggling opportunities (Global Initiative and RHIPTO, 2015). Interviews with Tebu smugglers, a nomadic African clan in the eastern Sahel, have revealed how dozens of convoys filled with 28-30 migrants each are smuggled to southern Libya every week. Conservatively, this earns smugglers about USD 60000 per week (Reitano and Shaw, 2015). The smuggling of migrants across the Sahara to Libya commonly involves nomadic tribes such as the Tuareg and Tebu. They are familiar with the desert and its trade routes, and at their peak, were smuggling between 5 000-20 000 persons per year (Global Initiative and RHIPTO, 2015).

Since the Libyan crisis, the opportunity for and profitability of migrant smuggling has drastically increased. The heavy involvement of nomadic tribes in migrant smuggling, some inextricably tied to AQIM and its affiliates, has given AQIM access to this form of IFF, although it is thought that AQIM and its affiliates are intermittently involved in these activities, as the opportunity arises. 


\section{Networks and actors behind these financial flows}

AQIM has been a driving force and inspiration for the creation and continuation of many terrorist organisations in the region, both through the strategic development of autonomous terrorist groups and on account of disgruntled AQIM members creating their own movements. Moreover, the financing of AQIM relies heavily on its interactions with these other local movements, as well as regional populations. Relations among regional terrorist movements in the Sahel can be characterised by a "fluid dynamic" (Lacher, 2012). Among the more prominent of these organisations were the Mali-based group Ansar alDine (AAD) and Al-Mourabitoun (see Box 3.1). Both these groups were subsequently absorbed into the Jama'at Nusrat al Islam wal Muslimeen (JNIM) coalition, which remains the most active and potent of the violent Islamist extremist groups active in West Africa. The more aligned these organisations are, the more likely they are to pool resources, and to jointly undertake operations.

\section{Box 3.1. Prominent movements linked to AQIM and other terrorist networks}

AAD: The AAD emerged in 2011, led by lyad ah Ghali. The United States designated it as a foreign terrorist organisation two years later (US Department of State, 2013). AAD was allegedly created by AQIM leadership as an independent entity, and tasked with running local operations, expanding operations in the Sahel and controlling territory in Mali (UNSC, 2015). This strategy would allow AQIM to increase its local influence by proxy. No AQIM actions would be linked to the AAD (UNSC, 2015). Even though the two groups are distinct by design, law enforcement officials in Niger understood that AQIM does not actively recruit its own members. Rather, AAD screens potential recruits and places these individuals according to skillset and capacity (RDV-SCLCT-22092015).

Al-Mourabitoun: Formed in 2013, al-Mourabitoun is the combination of MUJAO and Mokhtar Belmokhtar's al-Mouakaoune or "Those who sign in blood" battalion (BBC, 2013a). With Belmokhtar as leader, al-Mourabitoun is the most influential group in the trafficking of contraband, weapons and drugs; it continues to collaborate and carry out attacks in association with AQ central and AQIM (UNSC, 2014c).

Others: In addition to collaboration among AAD and AQIM or AI-Mourabitoun and AQIM, the evidence points to the links between Boko Haram and Ansaru of Nigeria, as well as AI-Shabab of Somalia, with AQIM (Aronson, 2014). High-ranking officials have also expressed concern regarding the links between AQIM and parallel organisations such as Ansar al-Sharia in Libya and Tunisia, and indeed these are areas in which AQIM and its affiliates have grown their presence due to sustained military pressure in Mali (Rasmussen, 2015). Among regional movements, "differences in ideology are not mutually exclusive in terms of group membership, funding and coordination" (Aronson, 2014). These groups may provide logistical support and safe-haven to AQIM as needed such as when the Mali-based groups 
retreated to northern Africa. In turn, AQIM assumes the role of mentor to more fledgling terrorist groups, providing them with financial, tactical and operational support.

\section{Organisations in constant flux}

Organisations like the MNLA, AAD, MUJAO, FNLA and AQIM are constantly evolving. Blurring lines, merging networks and temporary alliances on the basis of group self-interest, and as part of a continual quest for more optimal ways of working (Lacher, 2012), are common features.

Aside from the historical links between AQIM and its affiliates, the actions of these groups throughout the Malian rebellion demonstrate the degree to which they function in unison. According to the UN, an alliance was formed in November 2012 between AQIM, the AAD and MUJAO, which led to the creation of joint offices near Gao, and development of a joint strategy (UNSC, 2014d). It is thought that terrorist groups aligned in 2012 for both financial and tactical reasons, and to create a more united front in anticipation of an inevitable international intervention (Briscoe, 2014).

Strategic alliances are not only formed between terrorist organisations, but also include criminal organisations, corrupt state officials and local populations. AQIM has engaged in "opportunistic hybridism," "in which criminal entrepreneurs, government officials and political and traditional leaders move easily between a range of identities and professions: formal traders, extremists, smugglers, kidnappers, civil servants, members of the national army or state-backed militia, and local and regional politicians" (Kavanagh and Ellis, 2014). Tuareg community members in Mali even acknowledge "there are people who have changed from Malian military, to separatist rebel, to jihadist, to French ally, all while being narcotraffickers" (Tinti, Reitano and Shaw, 2014). Many of these interactions, especially in the case of terrorism and organised crime, function on a "pay-as-you-go" system, a system characterised by occasional, mutually beneficial, arrangements (Alda and Sala, 2014).

Overlaps between AQIM and its affiliate organisations are also common, a fact that often dramatically affects AQIM's financial network. The differing financial structures and specialties of each group introduce a variety of revenue streams to AQIM. Depending on the current state of inter- and intra-group politics, the financial networks of AQIM's affiliates could be considered an extension of AQIM's own financial network.

Despite being the parent (or grandparent) of the multiplicity of new Islamic groups active in the Sahel/Sahara, AQIM's influence is now substantially diminished. It is now viewed as just one of the members of the JNIM coalition.

\section{Box 3.2. Emerging interactions between AQIM and ISIL}

Based on the brutality of its campaign and resulting migrant crisis, the Islamic State of Iraq and the Levant (ISIL) quickly become a central focus of the global security agenda. ISIL drew widespread support amassing tens of thousands of foreign terrorist fighters from across the globe. It was highly successful in securing territory in Syria and Iraq, and beyond the borders of these two countries, and managed to secure support and public pledges or allegiance from parallel Islamic extremist groups.

By 2017, an estimated 43 extremist organisations had pledged support to ISIL. The increased frequency with which groups pledged their allegiance to ISIL may have been due to various reasons, including ideological agreement, the success of ISIL, the creation of a united Salafist front or the fulfilment of strategic and operational needs. Many of these groups reside within the Middle East and North Africa (MENA) region, as well as in portions of West and Central Africa spanning Algeria, Tunisia, Libya and 
Egypt to Nigeria and Sudan (IntelCenter, 2015). Some groups include the aforementioned alMourabitoun, led by Mokhtar Belmokhtar, and Nigeria's highly active and violent Boko Haram (IntelCenter, 2015).

While many groups "joined forces" with ISIL, AQ has not followed suit. The leader of AQ central, Ayman al-Zawahiri, issued statements that $A Q$ did not recognise the caliphate ISIL was seeking to create (Lister, 2015). AQIM, an extension of AQ central, has also publicly denounced ISIL behaviours and methods, especially in the context of Libya. According to tweets in July 2015, AQIM referred to ISIL's activities in Derna, including an event that resulted in the deaths of Muslims, as "acts of corruption". It said the group had introduced conflict in Libya and "shed sacred blood" (Joscelyn, 2015a). The Mujahedeen Shura Council in Derna, which AQIM also supports, shared these sentiments (Joscelyn, 2015a).

Regardless of disparities between $A Q$ and ISIL, AQ central called on its supporters to co-operate with ISIL and its leader Abu al-Baghdadi (Lister, 2015). This call for co-operation attempts to reduce infighting within the Mujahideen and unify a Salafist front "to push back the enemies of Islam" (Lister, 2015). In essence, AQ viewed ISIL as a lesser evil than enemies of Islam, and determined a short-term alliance could help both organisations pursue their disparate, yet parallel, goals.

As AQIM's fortunes have declined, and ISIL's have remained strong (albeit under continued pressure from the international community), new groups have emerged from the fragmented swathe of Islamist extremism in the Sahel and are increasingly affiliating to ISIL over AQ (ACSS, 2019). This has led some analysts to conclude that if $A Q$ accepted a formal alignment with ISIL, this would effectively start a process that could result in the end of $A Q$ altogether (Hamming, 2018).

The counterbalance between declarations of allegiance and refusals to align with ISIL provides a unique insight into the evolution of extremist movements and how internal disputes are resolved. The information garnered from such circumstances could serve to inform the development of future counterterrorism policy at both national and international levels, and policy responses will vary widely depending on whether these extremist groups merge and unify or diverge and become rivals. 


\section{IFF implications and developmental impact of terrorism-related activities}

\section{A political economy conducive for IFFs and terrorism}

The political-economic balance and security within the Sahel and West Africa is greatly influenced by the roles and interactions of corrupt state officials, Islamic extremist groups, rebel groups and a native population that is party to regional trafficking and smuggling. There are vast criminal opportunities in the region due to state complicity and participation. These elements combine and comingle in a dynamic system that perpetuates IFFs through instability. Similarly, the pre-existing political environment in Mali and the greater Sahel is characterised by a prolonged struggle among Tuareg, Arab, Songhai and Fulani ethnic groups to achieve an independent and self-determined state. This movement continues to be influential in the region (Welsh, 2013).

AQIM's financial model, much like the group itself, has evolved over time, in response to a shifting political economic environment, fluid regional dynamics and evolving opportunities for financial gain in the Sahel. Historically, AQIM gained a large portion of its funds from KFR. But the group's membership and relations with its affiliates have also allowed it to engage in smuggling and trafficking in the Sahel, principally arms trafficking and the smuggling of contraband. To a lesser degree, and largely anecdotally, AQIM is thought to be involved in drug trafficking and the smuggling of migrants and counterfeits. AQIM and its affiliates take advantage of whatever activity is readily available and lucrative. These groups engage in alliances of financial convenience. If the union is both profitable and viable, they are willing to merge with organised crime on a "pay-as-you-go" basis (Alda and Sala, 2014). Intra- and inter-group politics and relationships are manipulated to best take advantage of IFFs, using each group's expertise, connections and networks to optimise profits. Essentially, Islamic extremist groups will take advantage of an opportunity to make money if they can justify their acts with a properly framed ideology and political rhetoric.

Islamic extremist groups have introduced illicit funds into the local economy by buying weapons, establishing training camps, paying salaries, bribing community members and providing financial support to its affiliates. People in the region reliant on the revenue, as well as those engaged with it in profitable relationships, further disperse these funds when they, too, interact with the economy. In a territory already economically depressed, any type of funding is welcome. Thus, dependency on IFFs, introduced by AQIM and its subsequent affiliates and derivatives, begins to develop. This, in turn, reinforces and perpetuates participation in IFF-linked activities.

To address the more specific issue of AQIM's links to IFFs, two specific factors must be considered. First, AQIM functions in a world that is in continual flux, a world "in which identities are just as dynamic as the illicit goods being trafficked and smuggled through the region" (Kavanagh and Ellis, 2014). As a result AQIM needs to be understood in relation to the intricate web that connects it to affiliated groups, organised 
crime, corrupt officials and local communities. Second, much participation by regional terrorist groups in illicit activity is opportunistic and profit-driven, although it is increasingly thought these groups are developing vested and organisational interests in such activities, fundamentally altering the way in which these groups operate. Where they initially used smuggling opportunistically, they now seek to "actively guard it and use ideological and political narratives to justify actions that are ultimately aimed at protecting access to trade routes" (Global Initiative and International Alert, 2014). There are clearly also deeply rooted systemic, cultural, religious and resource-based factors supporting the region's current political economic status, and their legitimacy and IFF involvements.

\section{Sources of IFFs}

In terms of the IFFs generated by AQIM, it is difficult to find evidence that is credible and reliable. The interception of smuggling convoys is exceptionally difficult due to lack of capacity, corruption, vast unpoliced regions and porous borders. As a result, much information linking AQIM to smuggling is anecdotal. Uncovering linkages between terrorism and illicit or informal activities presents the same challenge, and it is difficult to collect evidence that reflects anything more than subjective perceptions based on anecdotal information (Global Initiative, 2014).

Nonetheless, a thorough assessment of available literature and reports, point to several plausible assumptions about how AQIM acquires its funding. A vast majority of AQIM's revenues were drawn from KFR. KFR is opportunistic, yet high yield, such that AQIM's participation in KFR activities is both erratic and lucrative. Although the kidnapping of victims is often highly publicised, ransom payments are not, and there is public consensus among the international community that ransom payments will fuel further terrorism and loss of life (UNSC, 2014e).

Ransoms are typically paid by states, through the use of proxies, and these payments are often labelled as developmental aid to obscure them (Callimachi, 2014). Estimates of the revenues generated by AQIM and its affiliates in the area of KFR over the years vary but all converge in agreement that such amounts are considerable. Strategic Analysts, Straftor, for example, suggest that AQIM alone has accrued USD 116 million since 2003. Lacher (2013) found that Canada and several European governments paid USD 40-65 million to groups such as AQIM and MUJAO between 2008-12 (Gardner, 2013; Lacher, 2013), and the US Department of Treasury estimated that $A Q$ as a whole and its affiliates have garnered USD 165 million since 2008, according to the New York Times. AQIM has also increased its ransom demands over time. The average in 2011 was USD 5.4 million, nearly USD 1 million higher than in 2010 (CSS ETH Zurich, 2013). Individuals in captivity appear to serve as an informal reserve source of revenue for AQIM, when other revenue streams may not be viable. However, the greater insecurity in the region has led to a significant decline in the number of available western targets, and has increased the security under which they are protected. In addition, a greater number of competing groups and the pressure from the international military forces has made the challenge of holding victims for a protracted period of time far greater. As such, as an ongoing revenue stream, KFR has declined significantly.

The injection of KFR-related profits in the earlier years, however, allowed AQIM to invest extensively in developing its arsenal. In turn, financial power allowed AQIM to play a prominent role in the circulation of arms, both as consumer and trafficker. The trafficking of cigarettes, mainly through Mokhtar Belmokhtar, also provided AQIM with a revenue stream, although this stream has decreased since Belmokhtar's departure from the organisation. Smuggling other types of contraband and counterfeit goods plays a lesser role in AQIM funding. This type of smuggling is principally undertaken only if more lucrative commodities are unavailable. AQIM's link to drug trafficking could be highly profitable, but for now there is a lack of clear evidence that AQIM is actively involved in the trade and drawing a profit. At an organisational level, AQIM's involvement in drug trafficking is most likely restricted to opportunistic protection fees charged to trafficking convoys in the territory under its control (Lacher, 2012), although the consensus is that overland cocaine 
import/export via the Sahel through Libya is uncommon due to the instability in Libya and a French military presence across the Sahel.

\section{Expenditure}

Given levels of poverty in the Maghreb and Sahel and the lack of legitimate and stable employment, people turn to terrorism and rebel movements. Terrorists are known to issue payments in exchange for young fighters. Families are paid monthly and also receive a one-time "signing bonus" for the recruitment of their children (Lewis and Diarra, 2012). Receipts recovered from a former AQIM stronghold in Timbuktu, abandoned in 2013 after the French military intervention, have provided further details about how AQIM allocates its funds. These details include personnel management, operational initiatives and community outreach. In this particular instance, funds were allotted for the following: food, cleaning supplies, car parts, car repairs, cash advancements to commanders, payments to AQIM members, ammunition, fuel for the city's power station, the spread of propaganda and relatively large amounts for "workshops". AQIM funds also paid for sick children to see doctors, weddings and damage incurred by AQIM members to community property (Callimachi, 2014). The existence of AQIM receipts and its record-keeping might suggest a centralised financial structure, although it is believed that AQIM predominately functions as a "money-in, money-out" organisation (UK-Gov-Sec-230615). This means that money garnered by the group, often earned and used locally by individual members, is not collected in a central reserve. Rather, it is spent on day-to-day organisational essentials such as the expenses listed above (UK-Gov-Sec-230615).

AQIM, the largest and best-established terrorist group in the region, has been known to financially contribute to affiliated organisations. In some cases, these contributions are in the form of direct monetary transfers. In one instance, lyad Ag Ghaly, the leader of the AAD, allegedly received EUR 400000 from a leader of the AQIM Tariq ibn Ziyad Brigade in the Sahel (UNSC, 2015). Similarly, in 2012, a Nigerian national was stopped in Niger smuggling EUR 35000 along with two flash drives containing letters from the Emir of AQIM to the leader of Boko Haram (FATF and GIABA, 2013). This form of support is also seen in the relationship between AQ central and AQIM. Based on letters recovered in Abbottabad, AQ central called on its affiliate groups, specifically AQIM, to provide monetary, logistical and operational assistance to a revered Islamist with a vision to create an AQ "secret operational force" in Africa and West Asia (Lahoud et al., 2012).

AQIM also provides training to other groups. Using its own resources, AQIM and Belmokhtar reportedly established basic training camps in Mali to educate their own members, as well as those from other movements, including Boko Haram and terrorist groups from Tunisia and Algeria (Dreazen, 2013). Some of the organisations that send members to such camps are splinter factions of AQIM and its allies. Others are movements that were to some degree created by AQIM, such as the Tunisian Uqba Ibn Nafi Battalion.

The scenarios and interactions described above are an indication of how AQIM allocated its resources and interacts with its affiliates in the region. It is clear that, financially, AQIM is deeply entrenched in West Africa. Not only does it participate in the aforementioned IFFs, it also disbursed accrued revenue into both the formal and informal economy, as a means to maintain its organisation and pursue its goals. By spreading the proceeds of IFFs, the regional economy - already wanting in economic opportunities becomes more reliant on IFF-generating activities, which contributes to the region's instability.

Perhaps as important as the past engagement of AQIM and its affiliates in IFFs is the mentality that emerges from their behaviour. They demonstrate a high degree of organisational adaptation in an everchanging international environment. They do not hesitate to seize available opportunities to generate funds. The Chairman of the US Joint Chiefs of Staff, General Martin E. Dempsey, described the group dynamic exhibited in North and West Africa by AQIM, the AAD and Ansar al Sharia as "a syndicate of groups who come together episodically, when it's convenient to them, in order to advance their cause. 
Sometimes their cause is terrorism. Sometimes it is criminal. Sometimes it is arms trafficking" (US Department of Defense, 2013).

Regardless of whether AQIM derives substantial profits from or directly participates in activities producing IFFs, it has played a major role in their existence by sowing instability in the region. In addition to systemic corruption in the Malian government, AQIM and its allies greatly contribute to an environment that provides opportunities for those willing to take part in IFF endeavours. AQIM and its affiliates and derivatives must be viewed as an adaptive and opportunistic entity. It uses whatever resources it can to further its terrorist, ideological and criminal goals. Despite best efforts, it is evident that neither AQIM and its affiliates nor the external traffickers have been eradicated from the region. This has been demonstrated by the increased number of attacks on UN peacekeepers in Mali in the recent period. 


\section{Concluding remarks}

AQIM and its affiliates can be understood as facilitators and promoters of IFFs, but not as their root causes. Many factors in the region provide conditions conducive to IFFs and AQIM and affiliate activities in the region.

This paper did not set out to formulate a set of policy recommendations to enhance the fight against terrorism and to severe their ties to illicit financial flows; but rather served to illustrate a number of themes and policy issues warranting further attention.

Based on the findings presented in this paper, next steps could include creation a dedicated multidisciplinary task team made up of regional and national experts and stakeholders to think through the policy implications of the study. Such a group could usefully reference and/or be informed by existing initiatives, such as the G5 Sahel, and could consider a range of issues, including enhancing prevention mechanisms, through, for example, coordinated approaches to promote responsible business conduct; the development of regional initiatives to address radicalism and "counter violent extremism" (CVE); and strengthening security collaboration and coordination in the region, by improving communication between border authorities and security agencies, as well as strengthened information sharing and co-operation at the national (inter-agency) and international levels.

At the same time, any strategy seeking to reduce IFFs in West Africa, or the involvement of terrorist groups in them, should be focused on addressing state corruption, creating legitimate economic opportunities and moving towards greater financial inclusion, community engagement and stability to make alternative, non-criminal and productive sources of livelihood more readily available. Further policy work to address the challenge of poverty, and provide greater economic opportunities and sustainable livelihoods in the region, will clearly also be needed for an effective strategy to prevent or mitigate illicit financial flows and their underlying links to terrorist networks. The imperative to step up existing response strategies is all the more relevant in light of rapidly developing new forms of financing of terrorism, such as cyberterrorism and cryptocurrencies. 


\section{Annex A. Methodology}

In terms of methodology, this study employs secondary desk-based research and documents, bolstered by interviews with a number of subject matter experts in relevant fields. The interviews were carried out in person, or via email, Skype or phone based on availability. Experts in terrorist financing or terrorism-related issues at the international, national, state or local levels were the focus of these interviews.

The desk-based review focuses on the financial behaviour of AQIM and of its affiliated groups. Specific resources include academic publications, media reports, national reports, international reports and publications, perception-based surveys, and transcribed statements from high-ranking government officials. The desk-based review is predominantly a retrospective examination of AQIM and of its affiliates based on document interrogation.

Inherent issues, especially with document interrogation, are reliability; the potential for selection-bias that may reflect the author's opinions (validity); and inaccessible documents (Tellis, 1997). In terms of biases, many articles are chosen from Western media sources, as terrorism is a common focus within this region. To mitigate potential biases, the author sampled documents from a myriad of countries and outlets. Additionally, every attempt to triangulate facts, identify true origins of information and authenticate sources was carried out. Access-oriented issues were addressed through reliance on open source and published documents, as well as a thorough documentation of any cited resources in the reference section.

In addition to the main methodology, analysis of Boko Haram employed perception-based polls. These polls were used to gauge public sentiment in northeast Nigeria on terrorism-related topics because (i) Boko Haram is centralised in this region, and (ii) the local population is a target of attacks and a source of revenue for the group. Vibrand Research, headquartered in South Africa, carried out the survey using a mobile platform in combination with trained local counterparts. Surveys addressed the subject of Boko Haram and regional perceptions of various factors, such as safety, security, community activities, terrorist behaviour, interactions between terrorists and local communities, and the efficacy of national and international counter-terrorism measures. In total, two polls were administered: a 200-person exploratory poll split between two key cities, and a subsequent 900 -person poll split between three key cities. Based on findings of the exploratory study, a larger polling campaign was initiated. All locations were selected based on the level of Boko Haram presence and activity. Results were retrieved from Vibrand Research in September 2015. 


\section{References}

Abubakar, A. and J. Levs (5 May 2014), "II will sell them' Boko Haram leader says of kidnapped Nigerian girls", CNN, www.cnn.com/2014/05/05/world/africa/nigeria-abducted-girls/.

Africa Center for Strategic Studies (15 February 2019), "The Complex and Growing Threat of Militant Islamist Gorups in the Sahel", ACSS, https://africacenter.org/spotlight/the-complex-and-growingthreat-of-militant-islamist-groups-in-the-sahel/\#timelapse

Agence France Presse (15 June 2011), "Niger army hunts for Al-Qaeda after clash", Modern Ghana, www.modernghana.com/news/334619/67/niger-army-hunts-for-al-qaeda-after-clash.html

Ahmed, B. and S. Corbet (11 January 2013), "Mali islamist rebels capture Konna, send military into retreat", Huffington Post, www.huffingtonpost.com/2013/01/11/mali-islamist-rebels-send-militaryretreat_n_2456568.html.

Ahmed, I. (19 June 2018), "Wanted terrorist Mokhtar Belmokhtar said to be still alive", VOA news, https://www.voanews.com/a/wanted-terrorist-mokhtar-belmokhtar-said-to-still-be-alive/4445477.html

Al Jazeera (21 May 2015), "French special forces 'kill al-Qaeda leader in Mali"', Aljazeera English, www.aljazeera.com/news/2015/05/french-special-forces-kill-al-qaeda-leader-mali-150520203048981.html.

Alaoui, H. (5 January 2011), "Morocco breaks up al-Qaeda-linked terrorist cell”, Boston Globe, www.boston.com/news/world/africa/articles/2011/01/05/morocco_breaks_up_al_qaida_linked_terrorist_cell/.

Alda, E. and J. Sala (2014), "Links between terrorism, organized crime and crime: The case of the Sahel region", Stability: International Journal of Security \& Development, Vol. 3/1, Ubiquity Press, London, www.stabilityjournal.org/articles/10.5334/sta.ea/.

Anderson, C. (2013), "Written evidence from the Joliba Trust", Foreign Affairs Committee, Parliament of the United Kingdom, www.publications.parliament.uk/pa/cm201314/cmselect/cmfaff/86/86vw09.htm\#footnote_28.

Anon (2013), Eight Steps to Counter the Drug Trade in West Africa, US Senate Caucus on International Narcotics Control, One Hundred Thirteenth Congress, First Session, Washington, D.C.

Armed Conflict Location and Event Data Project (ACLED), 2019, "The new normal: continuity and Boko Haram's violence in North East Nigeria", https://www.acleddata.com/2019/02/11/the-new-normalcontinuity-and-boko-harams-violence-in-north-east-nigeria/

Aronson, S.L. (28 April 2014), "AQIM's threat to Western interest in the Sahel", Combating Terrorism Center blog, www.ct.usma.edu/posts/aqims-threat-to-western-interests-in-the-sahel.

Associated Press (2013), Mali-Al-Qaida's Sahara Playbook, Associated Press, http://hosted.ap.org/specials/interactives/_international/_pdfs/al-gaida-manifesto.pdf.

Bargent, J. (8 April 2013), "Arrests point to FARC ties to AI Qaeda in North Africa", InSight Crime blog, www.insightcrime.org/news-briefs/arrests-point-to-farc-ties-to-al-qaeda-in-north-africa.

BBC (22 April 2015a), "Boko Haram crisis: Nigeria begins Sambisa ground offensive”, BBC News blog, www.bbc.com/news/world-africa-32416155.

BBC (14 October 2015b), "Boko Haram crisis: US deploys troops in Cameroon", BBC News blog, 
www.bbc.com/news/world-africa-34533820.

BBC (27 March 2015c), "Boko Haram HQ Gwoza in Nigeria 'retaken"”, BBC News blog, www.bbc.com/news/world-africa-32087211.

BBC (6 April 2015d), Dutch hostage Sjaak Rijke freed in Mali, BBC News blog, www.bbc.com/news/worldafrica-32195723.

BBC (15 June 2015e), "Profile: Mokhtar Belmokhtar", BBC News blog, www.bbc.com/news/world-africa21061480.

BBC (10 December 2014a), "Last French hostage Lazarevic freed in Mali”, BBC News blog, www.bbc.com/news/world-europe-30396903.

BBC (12 December 2014b), "Serge Lazarevic: Mali confirms militants freed for French hostage", BBC News blog, www.bbc.com/news/world-africa-30450092.

BBC (22 August 2013a), "Belmokhtar's militants 'merge' with Mali's Mujao", BBC News blog, www.bbc.com/news/world-us-canada-23796920.

BBC (17 January 2013b), "Profile: Al-Qaeda in North Africa", BBC News blog, www.bbc.com/news/worldafrica-17308138.

Blair, D. (10 January 2015), "Boko Haram is now a mini-Islamic state with its own territory", The Telegraph, www.telegraph.co.uk/news/worldnews/africaandindianocean/nigeria/11337722/Boko-Haram-is-nowa-mini-Islamic-State-with-its-own-territory.html.

Blair, D. (10 July 2012), "Mali: How the West cleared the way for al-Qaeda's African march", The Telegraph, www.telegraph.co.uk/news/worldnews/africaandindianocean/mali/9390601/Mali-how-the-Westcleared-the-way-for-al-Qaedas-African-march.html.

Briscoe, I. (2014), "Crime after Jihad: Armed groups, the state and illicit business in post-conflict Mali", Clingendael, Netherlands Institute for International Relations blog, www.clingendael.nl/publication/crimeafter-jihad-armed-groups-state-and-illicit-business-post-conflict-mali.

Brown, D.E. (2013), "The challenge of drug trafficking to democratic governance and human security in West Africa", The Letort Papers, Strategic Studies Institute, US Army War College, Carlisle, www.wacommissionondrugs.org/wp-content/uploads/2013/05/pub1151.pdf.

Callimachi, R. (24 July 2014), "Paying ransoms, Europe bankrolls Qaeda terror”, New York Times, www.nytimes.com/2014/07/30/world/africa/ransoming-citizens-europe-becomes-al-qaedas-patron.html? r=1.

Callimachi, R. (29 December 2013a), "\$0.60 for cake: Al-Qaida records every expense", www.pulitzer.org/files/2014/international-reporting/callimachi/01bcallimachi2014.pdf.

Callimachi, R. (28 May 2013b), "AP exclusive: Al-Qaida rips into prima donna terrorist for failing to deliver big operations", Associated Press, www.pulitzer.org/files/2014/internationalreporting/callimachi/02callimachi2014.pdf.

Callimachi, R. (14 February 2013c), "In Timbuktu, al Qaida left behind a manifesto", Associated Press, www.ap.org/Content/AP-In-The-News/2013/In-Timbuktu-al-Qaida-left-behind-a-manifesto.

Camara, K. (2015), “Mali's moment of truce”, Al Jazeera, http://america.aljazeera.com/opinions/2015/5/malismoment-of-truce.html.

Campbell, J., R. Bunche and J. Pham (14 January 2014), "Does Washington have a stake in the Sahel?", Council on Foreign Relations, Expert Brief blog, www.cfr.org/africa-sub-saharan/doeswashington-have-stake-sahel/p32195.

Chivvis, C.S. and A. Liepman (2013), North Africa's Menace: AQIM's Evolution and the US Policy Response, Research Report Series, Rand Corporation, www.rand.org/pubs/research_reports/RR415.html.

Chrisafis, A. et al. (25 January 2013), "Algeria hostage crisis: The full story of the kidnapping in the desert”, The Guardian, www.theguardian.com/world/interactive/2013/jan/25/algeria-hostage-crisis-full-story. 
Cocks, T. (26 April 2013), "Nigerian Islamists got \$3.15 million to free French hostages-document", Reuters, http://uk.reuters.com/article/2013/04/26/uk-france-hostages-idUKBRE93P0ZG20130426.

Conflict Armament Research \& Small Arms Survey (2013), Rebel Forces in Northern Mali: Documented Weapons, Ammunition and Related Materiel, www.conflictarm.com/wpcontent/uploads/2014/09/Rebel Forces in Northern Mali.pdf.

CSS ETH Zurich (2013), "Kidnapping for ransom as a source of terrorism funding", CSS Analysis in Security Policy, Vol. 141, CSS ETH Zurich, www.css.ethz.ch/publications/pdfs/CSS-Analysis-141-EN.pdf.

Der Spiegel (30 July 2007), "Kidnapping boom in Afghanistan and Iraq: Should Germany pay to free hostages?", Der Spiegel, www.spiegel.de/international/germany/kidnapping-boom-in-afghanistan-and-iraqshould-germany-pay-to-free-hostages-a-497269.html.

Domonoske, C. (14 June 2015), "US air strikes in Libya kill Algerian militant Mokhtar Belmokhtar", NPR, The Two-Way, www.npr.org/sections/thetwo-way/2015/06/14/414477190/u-s-airstrikes-in-libya-kill-algerianmilitant-mokhtar-belmokhtar

Dreazen, Y. (2013), "Mali: The new terrorist training ground", The Atlantic, October, www.theatlantic.com/magazine/archive/2013/10/the-new-terrorist-training-ground/309446/.

Egwuatu, P. and E. Elebeke (14 October 2015), "Declare state of emergency on cattle rustling", Northern Governors blog, www.vanguardngr.com/2015/10/declare-state-of-emergency-on-cattle-rustling-northerngovernors/.

FATF and GIABA (2013), Terrorist Financing in West Africa, Financial Action Task Force, Paris and the Inter-Governmental Action Group against Money Laundering in West Africa, Dakar, www.fatfgafi.org/media/fatf/documents/reports/tf-in-west-africa.pdf.

Flood, Z. (9 January 2011), "Two French hostages killed by al-Qaeda kidnappers during failed rescue attempt", The Telegraph, www.telegraph.co.uk/news/worldnews/africaandindianocean/niger/8248977/TwoFrench-hostages-killed-by-al-Qaeda-kidnappers-during-failed-rescue-attempt.html.

Follorou, J. (11 March 2014), "Jihadists return to northern Mali a year after French intervention”, The Guardian.

Freeman, C. (26 January 2013), "Revealed: How Saharan caravans of cocaine help to fund al-Qaeda in terrorists' North African domain", The Telegraph,

www.telegraph.co.uk/news/worldnews/africaandindianocean/mali/9829099/Revealed-how-Saharan-caravans-ofcocaine-help-to-fund-al-Qaeda-in-terrorists-North-African-domain.html.

Gardner, F. (1 November 2013), "Sahara kidnappings: A massive money making business", BBC News blog, www.bbc.com/news/world-africa-24764316.

Gberie, L. (2015), Crime, Violence and Politics: Drug Trafficking and Counternarcotics Policies in Mali and Guinea, Center for 21st Century Security and Intelligence, Latin America Initiative, Brookings Institution, Washington, D.C., www.brookings.edu/ /media/Research/Files/Papers/2015/04/global-drugpolicy/Gberie--Mali-and-Guinea-final.pdf?la=en.

Giles, C. (2019), “Nigerian elections: Has Boko Haram been defeated?", BBC, 8 February 2019, https://www.bbc.co.uk/news/world-africa-

47047399?intlink_from_url=https://www.bbc.co.uk/news/topics/c50znx8v435t/bokoharam\&link_location=live-reporting-story

Global Initiative (2014), “Angela Me," Global Initiative Network Profiles, May, Global Initiative against Transnational Organized Crime, Geneva, www.globalinitiative.net/download/globalinitiative/GIN\%20Interview $\% 20-\% 20$ Angela $\% 20 \mathrm{Me} \% 20-\% 20$ May $\% 202014$.pdf.

Global Initiative (31 December 2013), "Kidnapping for ransom: Everyman's organized crime”, Analyzing Organized Crime blog, Global Initiative against Transnational Organized Crime, Geneva, www.globalinitiative.net/kidnappingdec13/. 
Global Initiative and International Alert (31 December 2014), "Sustainable approaches to countering organised crime in Mali and the Sahel", Government, Development \& State Fragility blog, Global Initiative against Transnational Organized Crime, Geneva, www.globalinitiative.net/sustainableapproaches-to-countering-organised-crime-in-mali-and-the-sahel/.

Global Initiative and RHIPTO (2015), "Libya: A growing hub for criminal economies and terrorist financing in the Trans-Sahara", Policy Brief, 11 May 2015, Global Initiative against Transnational Organized Crime, Geneva, www.globalinitiative.net/download/globalinitiative/Libya\%20Criminal\%20Economies\%20in\%20the\%20trans-Sahara\%20-\%20May\%202015.pdf.

Hamming, T.R. (13 December 2018), "ISIS's charm offensive toward al-Qaeda in the Islamic Maghreb", Middle East Institute, https://www.mei.edu/publications/isiss-charm-offensive-toward-al-qaeda-islamicmaghreb

Harmon, S. (2014), Terror and insurgency in the Sahara-Sahel region: Corruption, Contraband, Jihad and the Mali War of 2012-2013, Ashgate Publishing Limited, Surrey.

Harmon, S. (2010), "From GSPC to AQIM: The evolution of an Algerian Islamist terrorist group into an AlQa'ida affiliate and its implication for the Sahara-Sahel region", Concerned Scholars, Vol. 85, Spring, http://concernedafricascholars.org/docs/bulletin85harmon.pdf.

Hirsch, A. (14 January 2013a), "Mali conflict: France has opened the gates of hell, say rebels", The Guardian.

Hirsch, A. (2 May 2013b), "Cocaine flows through Sahara as al-Qaida cashed in on lawlessness", The Guardian, www.theguardian.com/world/2013/may/02/cocaine-flows-through-sahara-al-qaida.

Ibrahim, M. (28 September 2015), "Cattle rustlers profit from Boko Haram bonanza", IRIN, www.irinnews.org/report/102040/cattle-rustlers-profit-from-boko-haram-bonanza.

IntelCenter (2015), Islamic State's 35 Global Affiliates Interactive World Map, http://intelcenter.com/maps/isaffiliates-map.html.

Joscelyn, T. (9 July 2015a), "Al Qaeda in the Islamic Maghreb backs jihadists fighting Islamic state in Derna, Libya", The Long War Journal blog, www.longwarjournal.org/archives/2015/07/al-qaeda-in-theislamic-maghreb-backs-iihadists-fighting-islamic-state-in-derna-libya.php.

Joscelyn, T. (19 June 2015b), "Al Qaeda in the Islamic Maghreb says Mokhtar Belmokhtar is 'alive and well"', The Long War Journal blog, www.longwarjournal.org/archives/2015/06/al-qaeda-in-the-islamicmaghreb-says-mokhtar-belmokhtar-is-alive-and-well.php.

Kaidanow, T.S. (2014), Presentation at the House Foreign Affairs Committee, Subcommittee on Terrorism, Non-proliferation, and Trade, US Department of State, Washington, D.C., 10 June 2014, www.state.gov/j/ct/rls/rm/2014/227413.htm.

Kavanagh, C. and S. Ellis (2014), "Comment: on the global initiative paper 'lllicit trafficking and instability in Mali”, Government, Development \& State Fragility blog, Global Initiative against Transnational Organized Crime, Geneva, www.globalinitiative.net/comment mali/.

Lacher, W. (2013), "Challenging the myth of the drug-terror nexus in the Sahel", Background Paper, No. 4, West Africa Commission on Drugs, Geneva, www.wacommissionondrugs.org/wpcontent/uploads/2013/09/Challenging-the-Myth-of-the-Drug-Terror-Nexus-in-the-Sahel-Wolfram-Lacher.pdf.

Lacher, W. (2012), "Organized crime and conflict in the Sahel-Sahara region", The Carnegie Papers, Middle East, September 2012, Carnegie Endowment for International Peace, Washington, D.C., http://carnegieendowment.org/files/sahel_sahara.pdf.

Lahoud, N. et al. (2012), "Letters from Abbottabad: Bin Ladin side-lined?", The Harmony Program, 3 May 2012, The Combating Terrorism Program at West Point, West Point, New York, www.ctc.usma.edu/wpcontent/uploads/2012/05/CTC_LtrsFromAbottabad_WEB_v2.pdf.

Laub, Z. and J. Masters (2015), "Al-Qaeda in the Islamic Maghreb", CFR Backgrounders, 27 March 
2015, Council on Foreign Relations, New York, www.cfr.org/terrorist-organisations-and-networks/al-gaedaislamic-maghreb-aqim/p12717.

Lebovich, A. (4 April 2011), "AQIM and Libya's missing weapons", Al-Wasat blog, https://thewasat.wordpress.com/2011/04/04/aqim-and-libyas-missing-weapons/.

Letouze, E. and S. Cramer (2013), "Kidnapping paid the bills for Jihadist groups in Mali. Now what?", IPI Global Observatory blog, http://theglobalobservatory.org/2013/02/kidnapping-paid-the-bills-for-jihadist-groupsin-mali-now-what/.

Lewis, D. and A. Diarra (25 October 2012), "Special report: In the land of "gangster-jihadists", Reuters, www.reuters.com/article/2012/10/25/us-mali-crisis-crime-idUSBRE89007Y20121025.

Lister, T. (15 September 2015), "Al Qaeda leader to ISIS: You're wrong, but we can work together", CNN, www.cnn.com/2015/09/14/middleeast/al-zawahiri-al-qaeda-isis-olive-branch/.

Look, A. (17 October 2010), "Morocco says dismantled international drug trafficking ring linked to terrorists", VOA News, www.voanews.com/content/morocco-says-dismantled-international-drug-traffickingring-linked-to-terrorists-105188824/160164.html.

Louet, S., N. Vincour and M. Habboush (7 May 2013), "France says taking AQIM threat seriously after video", Reuters.

Luna, D. (2014), "Trans-African security: Combating illicit trafficking along the crime-terror continuum", presentation at AFSEC 14, Casablanca, 14 February 2014, www.state.gov/j/in//rls/rm/2014/222591.htm.

Maclean, R. and I Abrak, "Boko Haram returns more than 100 schoolgirls kidnapped last month", The Guardian, 21 March 2018

Malakooti, A., T. Benattia and E. Davin (2013), "Mixed migration: Libya at the crossroads", report commissioned by the UNHRC-Tripoli November 2013, www.altaiconsulting.com/mixedmigrationlibya/Altai Consulting-UNHCR-Mixed Migration Libya.pdf.

Matfess, H. (2017) Women and the War on Boko Haram, Wives,Weapons, Witnesses, Zed Books: London

Mben, P. (7 February 2015), "Im Reich des Schrecklichen" [In the Empire of the Cruel], Der Spiegel, www.spiegel.de/spiegel/print/d-131696295.html.

Mben, P.H. and J. Puhl (21 January 2013), "'Gates of Hell': Mali conflict opens new front in war on terror", Spiegel Online International, www.spiegel.de/international/world/mali-offensive-opens-new-front-inthe-fight-against-terror-a-878750.html.

McElroy, D. (29 May 2013), "Al-Qaeda's scathing letter to troublesome employee Mokhtar Belmokhtar reveals inner workings of terrorist group", The Telegraph, www.telegraph.co.uk/news/worldnews/algaeda/10085716/Al-Qaedas-scathing-letter-to-troublesome-employee-Mokhtar-Belmokhtar-reveals-innerworkings-of-terrorist-group.html.

Meilhan, P. and G. Botelho (8 March 2013), "French minister: 'Tons' of Islamists' heavy weapons found in Mali", CNN, www.cnn.com/2013/03/08/world/africa/mali-unrest/index.html.

National Consortium for the Study for Terrorism and Responses to Terrorism (START), (2019), Global Terrorism Database [Data file Sahel],

https://www.start.umd.edu/gtd/search/Results.aspx?search=sahel\&sa.x=0\&sa.y=0\&sa=Search

NCTC (2015), "Al-Qaida in the lands of the Islamic Maghreb", Counter Terrorism Guide, National Counterterrorism Center, Washington, D.C., www.nctc.gov/site/groups/aqim.html.

Newton, J. (2015), "Nigeria army says it has rescued 200 girls and 93 women that were kidnapped by Boko Haram", The Daily Mail, www.dailymail.co.uk/news/article-3059667/Nigeria-army-says-rescued-200girls-93-women-Sambisa-Forest.html.

NFIU (2013), Trends and Typologies Report on Terrorism Financing in Nigeria, Nigerian Financial Intelligence Unit, Abuja, www.nfiu.gov.ng/images/Downloads/downloads/tf.pdf. 
Odunsi, W. (23 January 2015), "Military set for final onslaught on terrorists", The Daily Post, http://dailypost.ng/2015/01/23/military-set-final-onslaught-terrorists/.

Ould, M. (2011), The Many Faces of Al Qaeda in the Islamic Maghreb, Geneva Centre for Security Policy, Geneva.

Powelton, F. (31 October 2012), "Le Sahel, terre prisée par les trafiquants de drogue", A la une blog, Sahel Intelligence, http://sahel-intelligence.com/3007-le-sahel-terre-prisee-par-les-trafiquants-de-drogue.html.

Powelton, F. (3 November 2010), "Exclusif: Une réunion secrète des cartels de la drogue en GuinéeBissau, AQMl", Anti-terrorism blog, Sahel Intelligence,

Rasmussen, N.J. (2015), "Current terrorist threat to the United States", presentation to the Senate Select Committee on Intelligence, Washington, D.C., 12 February 2015, www.nctc.gov/docs/Current Terrorist Threat to the United States.pdf.

Reitano, T. and M. Shaw (2015), Fixing a Fractured State? Breaking the Cycles of Crime, Conflict and Corruption in Mali and Sahel, Global Initiative against Transnational Organized Crime, Geneva, www.globalinitiative.net/download/global-initiative/Global\%20lnitiative\%20\%20Fixing $\% 20$ a $\% 20$ Fractured\%20State $\% 20-\% 20$ April\%202015.pdf

Reitano, T. and M. Shaw (2014), People's Perspectives of Organised Crime in West Africa and the Sahel, Institute for Security Studies, Pretoria.

Reuters (30 January 2013), "Troops scour Malian cities for rebel's weapons”, Times of Malta, www.timesofmalta.com/articles/view/20130130/world/Troops-scour-Malian-cities-for-rebels-weapons.455442.

Roggio, B. (15 February 2013), "Al Qaeda in Mali sought to hide foreign designs", The Long War Journal blog, www.longwarjournal.org/archives/2013/02/al qaeda in mali sou.php.

Rotella, S. (19 December 2009), “US prosecution links drugs to terrorism”, Los Angeles Times, http://articles.latimes.com/2009/dec/19/nation/la-na-al-qaeda-cocaine19-2009dec19.

Sahara Overland (2015), Kidnappings, http://sahara-overland.com/kidnappings/ (accessed 25 June 2015).

Sherwood, H. (27 October 2014), "Boko Haram abductees tell of forced marriage, rape, torture and abuse", The Guardian, www.theguardian.com/world/2014/oct/27/boko-haram-forced-marriage-rape-tortureabuse-hrw-report.

Shurkin, M. (2014), France's War in Mali: Lessons for an Expeditionary Army, RAND Corporation, Santa Monica.

Smith, D. (2015), "Schoolgirls kidnapped by Boko Haram 'brainwashed to fight for the group"', The Guardian, www.theguardian.com/world/2015/jun/29/schoolgirls-kidnapped-boko-haram-brainwashed-fightgroup.

Tellis, W. (1997), "Application of a case study methodology", The Qualitative Report, Vol. 3/3, Nova Southeastern University, Fort Lauderdale, www.nova.edu/ssss/QR/QR3-3/tellis2.html.

Thornberry, W. and J. Levy (2011), "Al Qaeda in the Islamic Maghreb", Case Study, No. 4, September 2011, Center for Strategic and International Studies, Washington, D.C., http://csis.org/files/publication/110901_Thornberry_AQIM_WEB.pdf.

Tinti, P., T. Reitano and M. Shaw (2014), Illicit Trafficking and Instability in Mali: Past, Present and Future, Global Initiative against Transnational Organized Crime, Geneva.

Ugwuanyi, S. (16 October 2015), "I won't resign if Boko Haram is not defeated by December-Buhari", The Daily Post, http://dailypost.ng/2015/10/16/i-wont-resign-if-boko-haram-is-not-defeated-by-decemberbuharil.

UN (2015), "MINUSMA United Nations Multidimensional Integrated Stabilization Mission in Mali: MINUSMA Facts and Figures", webpage, www.un.org/en/peacekeeping/missions/minusma/facts.shtml (accessed 15 July 2015). 
UN (2013), "MINUSMA United Nations Multidimensional Integrated Stabilization Mission in Mali: MINUSMA Resources", webpage, www.un.org/en/peacekeeping/missions/minusma/resources.shtml (accessed 25 July 2015).

UNODC (2014), Colombia: Coca Cultivation Survey 2013, United Nations Office on Drugs and Crime, Geneva.

UNODC (2013a), Transnational Organized Crime in West Africa: A Threat Assessment, www.unodc.org/documents/data-and-analysis/tocta/West_Africa_TOCTA_2013_EN.pdf, United Nations Office on Drugs and Crime, Geneva.

UNODC (2013b), World Drug Report 2013, United Nations Office on Drugs and Crime, Geneva.

UNODC (2011), Estimating Illicit Financial Flows Resulting From Drug Trafficking and Other Transnational Organized Crimes, United Nations Office on Drugs and Crime, Geneva.

UNODC (2007), Cocaine Trafficking in West Africa: The Threat to Stability and Development (with special reference to Guinea-Bissau), United Nations Office on Drugs and Crime, Geneva, www.unodc.org/documents/data-and-analysis/west africa cocaine report 2007-12 en.pdf.

UNSC (2015), QDe.135 ANSAR EDDINE: Narrative Summaries of Reasons for Listing, United Nations Security Council, New York.

UNSC (2014b), QDe.134 Mouvement Pour L'Unification et le Jihad en Afrique de l'Ouest (MUJAO): Narrative Summaries of Reasons for Listing, United Nations Security Council, New York.

UNSC (2014c), QDe.141 AL Mourabitoun: Narrative Summaries of Reasons for Listing, United Nations Security Council, New York.

UNSC (2014d), QDi.232 Abdelmalek Droukdel: Narrative Summaries of Reasons for Listing, United Nations Security Council, New York.

UNSC (2014e), Security Council Adopts Resolution 2133 (2014), Calling upon States to Keep Ransom Payments, Political Concessions from Benefiting Terrorist, United Nations Security Council, New York, www.un.org/press/en/2014/sc11262.doc.htm.

UNSC (2013), Narrative Summaries of Reasons for Listing: QDi.136 Mokhtar Belmokhtar, United Nations Security Council, New York.

UNSC (2012), 6709th meeting SC/10533: Spiking Arms Proliferation, Organized Crime, Terrorism Part of Fallout from Libyan Crisis afflicting Sahel, United Nations Security Council, New York.

UNSC (2010), Narrative Summaries Reasons for Listing: QDi.152 Saifi Ammari, United Nations Security Council, New York.

US AFRICOM Public Affairs (30 July 2012), "Transcript: Press conference in Senegal with General Ham", Newsroom blog, www.africom.mil/newsroom/transcript/10004/transcript-press-conference-in-senegalwith-general.

US Department of Defense (2013), Press Briefing by Secretary Panetta and General Dempsey from the Pentagon, Washington, D.C.

US Department of State Bureau of Counterterrorism (2014), Country Reports on Terrorism 2013, www.state.gov/documents/organization/225886.pdf.

US Department of State (2014), "Boko Haram and U.S. counterterrorism assistance to Nigeria", Fact Sheet, http://www.state.gov/r/pa/prs/ps/2014/05/226072.htm.

US Department of State (2013), "Terrorist designations of Ansar al-Dine", Media Note, http://www.state.gov/r/pa/prs/ps/2013/03/206493.htm.

US Department of State (2006), Fact Sheet: Distinctions Between Human Smuggling and Human Trafficking 2006, www.state.gov/m/ds/hstcenter/90434.htm.

US v. Oumar Issa, Harouna Toure, and Idriss Abdelrahman (2009), United States District Court Southern 
District of New York.

Vanguard (2014), "France ends Mali offensive, redeploys troops to restive Sahel", www.vanguardngr.com/2014/07/france-ends-mali-offensive-redeploys-troops-restive-sahel/.

Voice of Africa (2015a), "House of reps reveals number of kidnapped Boko Haram Victims since 2012", Voice of America, www.voiceofafrica.news/house-of-reps-reveals-number-of-kidnapped-boko-haram-victimssince-2012/.

Voice of Africa (2015b), "Nigeria military moves anti-Boko Haram HQ to Maiduguri", Voice of America, www.voanews.com/content/reu-nigeria-military-moves-anti-boko-haram-headquarters-tomaiduguri/2811945.html.

Weiss, C. (23 June 2015a), "AQIM Sahara branch releases video showing last two hostages in Mali", The Long War Journal blog, www.longwarjournal.org/archives/2015/06/aqim-sahara-branch-releases-videosshowing-last-two-hostages-in-mali.php.

Weiss, C. (4 March 2018), "JNIM confirms deaths of co-founder, senior leaders in French raids", The Long war Journal blog, https://www.longwarjournal.org/archives/2018/03/jnim-confirms-deaths-of-co-founder-seniorleaders-in-french-raids.php

Weiss, C. (10 February 2015b), "lyad Ag Ghaly reportedly in the Kidal region of Mali", The Long War Journal blog, www.longwarjournal.org/archives/2015/02/iyad ag ghaly reportedly in th.php.

Weiss, C. (5 January 2015c), "Jihadists in Mali step up attacks, kill 7 soldiers”, The Long War Journal blog, www.longwarjournal.org/archives/2015/01/violence_continues_i.php.

Weiss, C. (4 October 2014a), "9 UN troops killed in Mali ambush", The Long War Journal blog, www.longwarjournal.org/archives/2014/10/un troops killed in.php.

Weiss, C. (18 November 2014b), "Al Qaeda in the Islamic Maghreb video features French, Dutch hostages", The Long War Journal blog, www.longwarjournal.org/archives/2014/11/al qaeda in the isla 1.php.

Weiss, C. (18 December 2014c), "Tunisian Jihadist group posts pictures of spoils, claims attacks on Tunisian military", Threat Matrix blog, www.longwarjournal.org/archives/2014/12/tunisian_jihadist_group_posts.php.

Welsh, M.Y. (17 January 2013), "Making sense of Mali's armed groups", Aljazeera, www.aljazeera.com/indepth/features/2013/01/20131139522812326.html.

Wood, D. (20 February 2013), "Libyan weapons arming Al Qaeda militias across North Africa", The Huffington Post, www.huffingtonpost.com/2013/02/20/libyan-weapons-al-qaeda-north-africa_n_2727326.html.

\section{Interviews}

NIG-Gov-LE-201015, Nigerian Financial Intelligence Unit \& National Risk Assessment Secretariat, Nigeria, 20 October 2015.

NIG-Gov-Sec-121015, Office of the National Security Advisor, Nigeria, 19 October 2015.

RDV-SCLCT-22092015, Police Captain, Chief of Investigations, SCLCT, 22 September 2015.

UK-Gov-Sec-230615, Financial Flows Analyst, JNAC, Ministry of Defence, 23 June 2015. 


\section{Notes}

${ }^{1}$ All groups and individuals referred to as terrorists in this report are listed in the UN sanctions regime first established by resolution 1267 on 15 October 1999 and modified by resolutions 1333 (2000), 1390 (2002), 1455 (2003), 1526 (2004), 1617 (2005), 1735 (2006), 1822 (2008), 1904 (2009), 1989 (2011), 2083 (2012) and 2161 (2014) so that sanction measures apply to individuals and entities linked to AI Qaeda as per the UN ISIL (Da'esh) \& Al Qaeda Sanctions List: www.un.org/sc/suborg/en/sanctions/1267/aq sanctions list.

${ }^{2}$ MNLA is a nationalist group formed from notable clans within the Kel Adagh Tuareg tribal confederation in the region. It also includes people from many other communities in northern Mali. Many individuals involved had participated in earlier rebel movements. Peace agreements rendered them members of the Malian army, but many defected and joined the MNLA in 2012 (Shurkin, 2014). The MNLA, in an act of momentary mutual benefit, allied with AQIM and its affiliates, MUJAO pour l'Unification et le Jihad en Afrique de l'Ouest (Movement for Oneness and Jihad in West Africa) and Ansar al-Dine (AAD). Together, they sought to drive out Malian forces.

${ }^{3}$ Even at the height of the French intervention, the rhetoric from rebel leaders in Mali resembled a war cry more than a message of surrender (Hirsch, 2013a). An audio bite, alleged to be of a senior ranking AQIM member, called for attacks on French interests. This call to arms was echoed by AQIM-linked groups as well (Louet, Vincour and Habboush, 2013). Similarly, many locals in Gao believe that French airstrikes and troops only managed to scatter the Islamists, who went into hiding in the countryside, waiting for the French military withdrawal. AQIM and other regional terrorist or insurgent groups have previously hunkered down deep in the desert with food, weapons and gasoline. In this way, they avoid detection by external forces or drones (Dreazen, 2013).

${ }^{4}$ One case involved three AQIM-linked individuals who orchestrated a deal with undercover US Drug Enforcement Administration (DEA) agents. The agents posed as members of the Revolutionary Armed Forces of Colombia (FARC), a criminal/terrorist organisation that controls much of the cocaine industry in Colombia. These three individuals planned to transport $500-1000 \mathrm{~kg}$ of cocaine across the Sahel, stating that the smuggling routes were controlled by AQIM. They gave details regarding how AQIM would be integral to the protection and movement of the narcotics (US v. Oumar Issa, Harouna Toure and Idriss Abdelrahman, 2009). In October 2010, Morocco's Minister of the Interior announced the arrest of a 34-person drug ring. He described it as "an apparent coordination and confirmed collaboration' between drug traffickers and Al Qaeda of the Islamic Maghreb in the region" (Look, 2010). Similarly, in March of 2013, the US DEA reportedly arrested three Salafists tied to AQIM and two Colombians, one allegedly linked to FARC, on drug trafficking charges in Algeria. The FARC had supposedly made contact with local Salafists linked to AQIM, brokering an exchange of cocaine for cash and arms (Bargent, 2013). Another case involves Abdelkrim alTourig, leader of AQIM deceased in May 2015. Implicated in several operations against French forces, as well as numerous hostage scenarios and killings (Al Jazeera, 2015), he is reported to have acted as an AQIM representative at a "drug summit" in Guinea-Bissau in October 2010. However, this report relies on only one anonymous and unverifiable source. 


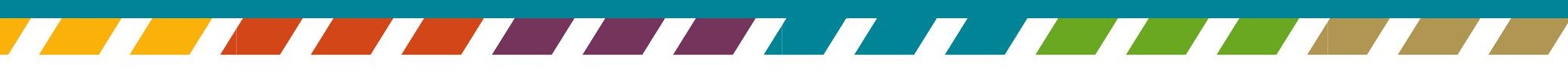

